\title{
OTEL YÖNETİCİLERİ BAKIŞ AÇISIYLA DENEYİM MODÜLLERİ VE DENEYIMM BOYUTLARI
}

Tuğrul AYYILDIZ ${ }^{1}$

$\ddot{O Z Z}$

\section{Anahtar Kelimeler: \\ Deneyimsel Pazarlama, \\ Deneyim Modülleri, \\ Deneyim Boyutlarn}

JEL Kodlarn:
M31,
Z32,
Z33

Keywords:

JEL Codes:

\author{
Received Date (Başvuru Tarihi): \\ Accepted Date (Kabul Tarihi): \\ Published Date (Yayın Tarihi):
}

$7 / 08 / 2020$

$8 / 09 / 2020$

$25 / 09 / 2020$

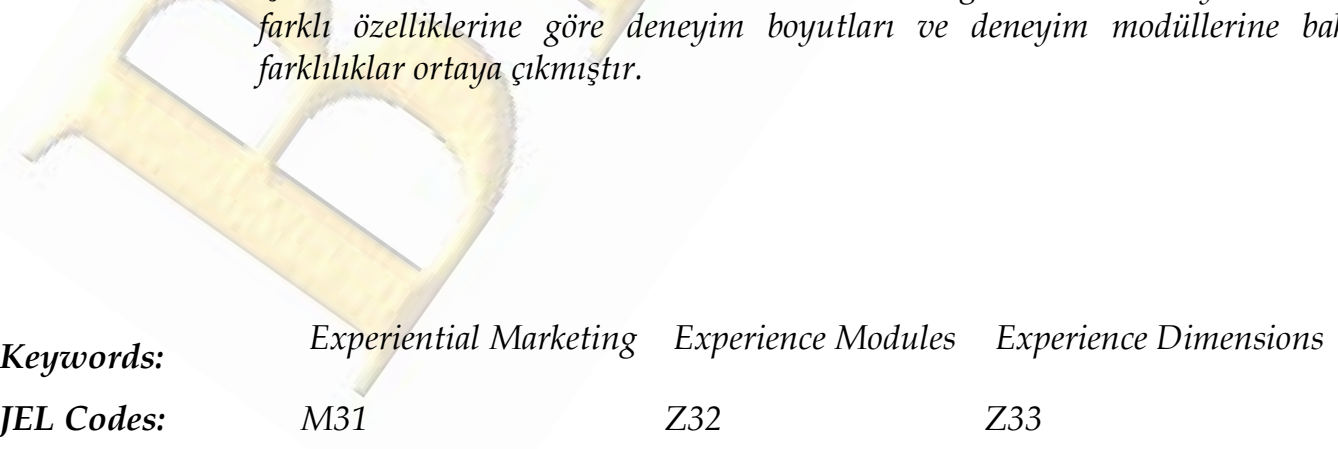

Tüketicilerin bir ürün ya da hizmet satın almalarnnda o ürün ya da hizmetin faydasının yanında kendilerine sunacağı olumlu deneyim de etkili olmaktadır. Otel işletmelerinde yaşanilan deneyimler daha da önemli olmaktadır. Turist konakladığı otelde yaşadı̆̆ farklı ve unutulmaz deneyimler sayesinde tatmin olmaktadır. Günümüzde tatmin olan turist sosyal medya aracılı̆̆ ile bazen anında otel işletmesinin tanıtımın yapmaktadır. Bu durum otel işletmesinin karlhlığın olumlu yönde etkilemektedir. Misafirlerine yaşatmış olduklarn deneyimler ile hem mevcut misafirlerinin tatmin ve sadakatini sağlayabilmekte hem de yeni misafirleri otel işletmelerine çekebilmektedirler. Bu nedenle otel işletmelerinde deneyim boyutlar ve deneyim modülleri misafirlerin olumlu deneyimler yaşayabilmeleri adına önem taşımaktadır. Bu doğrultuda bu çalışmanın temel amacı otel yöneticileri bakış açısıyla deneyimsel pazarlama modüllerinin ve boyutlarının incelenmesidir. Çalışma Kuşadası'ndaki 4 ve 5 yıldızl otel işletmelerinde gerçekleştirilmiştir. Çalı̧̧mada nicel yaklaşımlardan ilişkisel tarama modeli kullanılmıştır. Araştırma sonucunda deneyim modülleri ve boyutlar ortalamalar açısından genel anlamda iyi görünmekle birlikte işletmelerin bu konuda daha özenli davranmalarn gerekmektedir. Ayrica otel işletmelerinin farkl özelliklerine göre deneyim boyutları ve deneyim modüllerine bakış açılarında farklilıklar ortaya çımışıtır.
M31
Z32
Z33

${ }^{1}$ Dr. Öğr. Üyesi, Aydın Adnan Menderes Üniversitesi Turizm Fak., tayyildiz@adu.edu.tr, https://orcid.org/0000-0001-6332-975X 


\section{EXTENDED ABSTRACT}

\section{EXPERIENCE MODULES AND EXPERIENCE DIMENSIONS FROM THE PERSPECTIVES OF HOTEL MANAGERS}

\section{LITERATURE}

\subsection{RESEARCH SUBJECT}

Today, customers are not easily convinced and also, they are not able to make preferences as quickly as they were before. In such a situation, enterprises move away from traditional marketing strategies and tend towards the marketing strategies that focus on their consumer demands (Yetiş, 2015: 90). By 1990s, the experience economy, which prioritizes creating an experience in economic activities, brought experiential marketing to the forefront. Therefore, this situation included excitement and fun into the annoying practices of traditional marketing and the winds of change was launched (Yllmaz and Vahidli, 2020: 1456). The enterprises in the tourism industry are continually yielding new strategies in order to get ahead of their competitors. These strategies include offering different products to customers, presenting the product as an experience, managing customer experience, segmenting customers, managing customer relationships, and the concepts of destination branding and experiential marketing concepts (Çeltek, 2010: 1). In the study by Schmitt (1999) entitled "Experiential Marketing", five strategic experiential modules were revealed as an essential concept of experiential marketing. These five modules were examined under five headings as: sensory, emotional, intellectual, behavioural and relational (Schmitt, 1999: 60). In the study by Pine and Gilmore (1998), four dimensions of experience were revealed. These dimensions were entertainment, education, escape and aesthetics (Pine and Gilmore, 1998: 102). The main aim of this research is to reveal experience modules and experience dimensions implemented in hotels from hotel managers' perspectives.

\subsection{RESEARCH PURPOSE AND IMPORTANCE}

Enterprises try to ensure the satisfaction and loyalty of their customers through experiential marketing. In this way, they can both keep their existing customers and gain new customers. Thanks to the different experiences that hotel enterprises provide for their customers who prefer their facilities to stay in, the enterprises have a high possibility of turning them into regular customers. Today, hotel enterprises offer their customers different experiences in different departments from the beginning of check-in till check-out of the hotel. Tourists go through these different experiences in 5 modules as sensory, emotional, intellectual, behavioural and relational and in 4 dimensions as entertainment, education, aesthetics and escape. The fact that the hotel management works accordingly for the experiences that tourists go through in these modules and dimensions is an essential issue. It is also essential for the hotel management to pay attention to the features in these dimensions and modules so that tourists can have different experiences during their hotel accommodations. In this regard, the primary purpose of this study is to examine the experiential marketing modules and dimensions from the perspectives of hotel managers. In line with this primary purpose, revealing the differences between experience modules and experience dimensions according to the features of the hotels constitutes the sub-purpose of the study.

\subsection{CONTRIBUTION of the ARTICLE to the LITERATURE}

As a result of the literature review carried out, the studies on the experience modules and experience dimensions of the experiential marketing applied in the hotel enterprises were generally examined from the perspectives of customers. It was observed that there were quite a few studies from the perspectives of managers. The study is thought to contribute to the literature in this regard.

\section{DESIGN AND METHOD}

\subsection{RESEARCH TYPE}

Relational screening model, which is one of the quantitative research methods, was used in this study. 


\subsection{RESEARCH PROBLEMS}

The main problem of this study is to reveal how experiential marketing modules and dimensions are applied in the hotel enterprises from the perspectives of hotel managers.

\subsection{DATA COLLECTION METHOD}

In this study, a questionnaire was used as the data collection technique. The questionnaire created was composed of two main sections. In the first section of the questionnaire, there were the questions formed in order to determine the essential characteristics of the hotel enterprises. In the second section of the questionnaire, there was a 22-item scale composed of 4 dimensions as entertainment, education, aesthetics and escape, which was used to determine the perspectives of managers towards the experience dimensions. These questions were prepared as 5-point Likert type scale (I strongly disagree - I disagree - I neither agree nor disagree - I agree - I strongly agree). In the third section of the questionnaire, there was a 19-item scale composed of 5 dimensions as sensory, emotional, intellectual, behavioural and relational, which was used to determine the perspectives of managers towards the experience modules. These questions were prepared as 5-point Likert type scale (I strongly disagree - I disagree - I neither agree nor disagree - I agree - I strongly agree).

\subsection{QUANTITATIVE/ QUALITATIVE ANALYSIS}

As the data of the study were collected from 32 managers, the analyses in the study were performed according to the dimension mean scores by remaining faithful to the original scales. Since the number of participants in the study was low, nonparametric tests were applied in order to reveal the differences in the perspectives of the hotel managers towards the experience dimensions and experience modules according to the different features of the hotel enterprises.

\subsection{RESEARCH MODEL}

In this study, experience dimensions and experience modules were examined from the perspectives of the hotel managers. In addition, it was examined whether there were significant differences between the viewpoints of the managers on the experience modules and experience dimensions according to the different characteristics of the hotels.

\subsection{RESEARCH HYPOTHESES}

$\boldsymbol{H}_{1}$ : There is a significant difference between the perspectives of the participants towards the experience dimensions and experience modules according to the number of stars of the hotel enterprises they work in.

$\mathrm{H}_{2}$ : There is a significant difference between the perspectives of the participants towards the experience dimensions and experience modules according to the operational status of the hotel enterprises they work in.

$\mathrm{H}_{3}$ : There is a significant difference between the perspectives of the participants towards the experience dimensions and experience modules according to the operational period of the hotels.

$\boldsymbol{H}_{4}$ : There is a significant difference between the perspectives of the participants towards experience dimensions and experience modules according to the capacity of the hotels.

\section{FINDINGS AND DISCUSSION}

\subsection{FINDINGS as a RESULT of ANALYSIS}

As a result of the findings obtained in the study, it was determined that of the experience dimensions, the education dimension had the lowest mean score. According to the responses given by the participants, the aesthetic dimension had the highest mean score. When the mean scores of the experience modules were examined, it was observed that intellectual module had the lowest mean score, whereas emotional module had the highest mean score according to the responses given by the participants. It was revealed that there was no significant difference in the managers' perspective on experience dimensions and experience modules according to the number of stars and the operational status of the hotels. 
However, it was found that there was a significant difference in the education dimension and the perspectives of the managers towards intellectual, behavioural and relational modules in the hotels with different operational periods. Furthermore, it was also observed that there was a significant difference between the perspectives of the managers having different hotel capacities towards the emotional module, which was of the experience modules.

\subsection{HYPOTHESIS TEST RESULTS}

\begin{tabular}{|l|c|}
\hline \multicolumn{1}{|c|}{ HYPOTHESES } & RESULTS \\
\hline $\begin{array}{l}\text { H1: There is a significant difference between the perspectives of } \\
\text { the participants towards experience dimensions and experience } \\
\text { modules according to the number of stars of the hotel } \\
\text { enterprises they work in. }\end{array}$ & REJECTED \\
\hline $\begin{array}{l}\text { H2: There is a significant difference between the perspectives of } \\
\text { the participants towards experience dimensions and experience } \\
\text { modules according to the operational status of the hotel } \\
\text { enterprises they work in. }\end{array}$ & REJECTED \\
\hline $\begin{array}{l}\text { H3: There is a significant difference between the perspectives of } \\
\text { the participants towards experience dimensions and experience } \\
\text { modules according to the operation period of the hotels. }\end{array}$ & $\begin{array}{c}\text { ACCEPTED in terms of } \\
\text { education dimension and } \\
\text { intellectual, behavioural } \\
\text { and relational dimensions }\end{array}$ \\
\hline $\begin{array}{l}\text { H4: There is a significant difference between the perspectives of } \\
\text { the participants towards experience dimensions and experience } \\
\text { modules according to the capacity of the hotels. }\end{array}$ & $\begin{array}{l}\text { ACCEPTED in terms of } \\
\text { emotional module }\end{array}$ \\
\hline
\end{tabular}

\subsection{DISCUSSING the FINDINGS with the LITERATURE}

Considering the overall mean scores of the dimensions; it could be stated that while aesthetic dimension had the lowest mean score in the study conducted by Çoşkunoğlu (2019), education dimension had the highest mean score. Similarly, in the study conducted by Çeltek (2010), it was revealed that the education dimension had the lowest mean score, whereas escape dimension had the highest mean score. In this respect, this study could be said to have opposite findings when compared to the study conducted by Çoşkunoğlu (2019). However, it could be stated that the findings of the study conducted by Çeltek coincided with the findings of this study, with the education dimension having the lowest mean score. When the findings of the studies by Coşkunoğlu (2019) and Çeltek (2010) conducted similarly were compared, it was found that in the study conducted by Coşkunoğlu (2019), the behavioural module had the highest mean score while sensory module had the lowest mean score. In the study conducted by Çeltek (2010), it was revealed that the sensory/emotional module had the highest mean score while intellectual/behavioural module had the lowest mean score. In this regard, even though the dimensions were combined in the study conducted by Çeltek (2010), the findings of the study were similar to the findings of the current study.

\section{CONCLUSION, RECOMMENDATION AND LIMITATIONS}

\subsection{RESULTS of the ARTICLE}

As a result of the findings of the study, it could be said that experience dimensions and experience modules were applied above the moderate level in the 4-star and 5-star hotel enterprises in Kuşadası. There was not a difference in the perspectives of the managers in the hotel enterprises towards experience dimensions and experience modules according to the number of stars of the hotels and their operational status. However, there was a significant difference in the perspectives of the managers towards education dimension and intellectual, behavioural and relational modules in the hotels with different operation periods. Furthermore, it was observed that there was a significant difference between the perspectives of the participants with different hotel capacities towards the emotional module, which was of the experience modules.

\subsection{SUGGESTIONS BASED on RESULTS}

According to the findings of the study, hotel managers can respond to the expectations of their guests by teaching new things, especially to their guests who stay in their enterprises for different 
experiences. Besides, hotel enterprises can organize such courses as sports and hobby activities for their guests and be educatory for their guests. Thus, they can also help their guests to meet the experiences in terms of learning.

\subsection{LIMITATIONS of the ARTICLE}

This study was carried out through a questionnaire applied to the managers working in 4 and 5-star hotel enterprises operating in Kuşadası district, one participant from each hotel. Accordingly, together with the fact that this study can be carried out in different resort hotels, it can also be conducted in city hotels and thus, comparisons can be made as well. Furthermore, different perspectives can also be revealed by applying the study to all the employees or all the managers working in hotel enterprises. 


\section{GİRiş}

Günümüzde işletmeler pazarlama anlayışlarında farklılaşmalara gitmektedirler. Bunun sebepleri arasında ekonomik faaliyetlerin gelişmesi, küreselleşen rekabet ve tüketicilerin tüketim eğilimlerindeki değişiklikler sayılabilir. Günümüzde müşterilerde pazarda değişim göstermektedir. Müşteriler eskisi gibi kolay kolay ikna olmamakta ve kolay tercih yapamamaktadırlar. Böyle bir durum karşısında işletmeler geleneksel pazarlama stratejilerinden uzaklaşarak tüketici isteklerini odak noktasına alan pazarlama stratejilerine yönelmektedirler (Yetiş, 2015: 90). 1990'l1 y1llar geldiğinde ekonomik faaliyetlerde deneyim yaratmayı ön plana alan deneyim ekonomisi, deneyimsel pazarlamayı ortaya çıkarmıştır. Böylece bu durum geleneksel pazarlamanın can sıkan uygulamalarına heyecan ve eğlence katmış ve değişim rüzgarları başlamıştır. 2000'li yıllar geldiğinde ise teknolojik gelişmelerle birlikte iletişim ve reklam araçlarının yaygınlaşması tüketici karar ve tercihlerinde geleneksel pazarlama anlayışının iyice yetersiz kalmasına neden olmuştur (Yılmaz ve Vahidli, 2020: 1456).

Tüketici ve pazarlama araştırmaları, tüketicilerin ürünleri aradıklarında, alışveriş yaptıklarında ve hizmet aldıklarında ve onları tükettiklerinde deneyimlerin ortaya çıktığını göstermiştir (Brakus, Schmitt ve Zarantonello, 2009: 52). Tüketicilerin satın alma ile ilgili karar verme bakış açıları daha çok faydacı bir yol izlemektedir. Buna karşın deneyimsel bakış açısı ise hedonik faydayı ön plana almaktadır. Geleneksel pazarlamaya göre deneyimsel pazarlama, tüketimi rasyonel olduğu kadar çeşitli hedonik boyutları da içeren bir deneyim olarak görmektedir (Yetiş, 2015: 91,96).

Günümüz pazarında tüketici deneyimine dayanan işletme stratejileri, katılımı ve tüketici ile duygusal bir bağı destekleyerek benzersiz bir marka yaratma imkanı sağladığından, rekabetçi bir farklılaşma kaynağı haline gelmiştir. Küresel ekonomide en hızlı büyüyen sektörlerin çoğu deneyimsel tüketim ile bağlantılıdır. Bir örnek, deneyimlerin temel olduğu büyük projeksiyona sahip bir sektör olan turizmdir. Turizmin deneyimsel boyutu, turistlerin psikolojik refahını ve kişisel gelişimlerini besleme bağlantısı nedeniyle büyük bir patlama yaşamıştır (Garcia, Galindo ve Suarez, 2018: 23). Turizm araştırması, geleneksel "rasyonel-karar vericiler olarak turistler" 
görüşünden turist kararlarının hem deneyimsel hem de rasyonel belirleyicilerinin daha kapsamlı bir anlayışına doğru kaymaktadır. Fayda teorileri ve planlanan davranış teorisi gibi geleneksel teoriler turizm davranışını açıklamada sorunludur çünkü turizm tüketiminin deneyimsel yönlerini ihmal etmektedirler. Psikolojik süreçlere dayanan çift işlem teorileri bu sınırlamalara yöneliktir. Çift işlem teorisine göre, turistler karar verirken iki farklı ancak tamamlayıcı sistemle uğraşırlar: Sistem 1 hızlı, otomatik, deneyimsel ve duygusal faktörlerle ilgilidir, Sistem 2 yavaş, rasyonel, analitiktir ve rasyonel düşünme ile ilgilidir. Bu yeni karar verme teorileri turizm pazarlamacılarına destinasyonları tanıtmak ve turizm ürünleri / hizmetleri satmak için yenilikçi teknikler sunmaktadır. Zevk turistler fanteziler, duygular ve eğlence gibi deneyimsel faydalar aradıkça, ürün özelliklerine ve fonksiyonel faydalara (yani rasyonel faktörler) odaklanan geleneksel pazarlama etkili olmayabilir (Le, Scott ve Lohmann, 2019:220).

Turizm sektörü içerisinde yer alan işletmeler rakiplerinin önüne geçebilmek adına sürekli yeni stratejiler üretmektedirler. Bu stratejiler arasında müşterilerine farklı ürünler sunma, ürünü deneyim olarak sunma, müşteri deneyimi yönetimi, müşteri bölümlendirmesi, müşteri ilişkileri yönetimi, destinasyon markalama ve deneyimsel pazarlama kavramları yer almaktadır (Çeltek, 2010:1). Turizm işletmeleri içerisinde yer alan otel işletmeleri de yeni müşteriler elde etmek ya da mevcut müşterilerinin tatmin ve sadakatini sağlayabilmek için müşterilerine farklı deneyimler sunmaktadırlar. Günümüz rekabet ortamında otel işletmeleri rakiplerinden farklılaşmak adına farklı tür ve boyutlarda deneyimsel pazarlama uygulamaları gerçekleştirmektedirler. Bu doğrultuda bu çalışmanın temel amacı Kuşadsı'ndaki 4 ve 5 yıldızlı otel işletmelerinde uygulanan deneyim türleri ve deneyim boyutlarının incelenmesidir. Bu temel amaç doğrultusunda işletmelerin farklı özelliklerine göre uyguladıkları deneyim türleri ve boyutlarında istatistiksel olarak anlamlı farklılıkların olup olmadığının ortaya konması da alt amaç olarak belirlenmiştir. 


\section{KAVRAMSAL ÇERÇEVE}

\subsection{Deneyimsel Pazarlama}

Tüketiciciler her dönemde çok fazla seçeneğe sahiptir. Ancak günümüz tüketicileri, bugüne kadar olan her dönemden çok daha fazla ve karmaşık seçeneğe sahiptir. Ayrıca günümüz tüketicileri bu seçeneklerin peşinde koşmak için çeşitli araçlara da sahiptirler. Tüketiciler, ürünleri satın almaları adına kendileri için yayımlanan ürün mesajlarına karşı her geçen gün daha kapalı hatta bağışıklık kazanmış hale gelmişlerdir. Bu nedenle, tüketicilere ulaşmanın yolu onlara yaşayabilecekleri bir deneyim yaratmaktan geçmektedir (Saltık, 2011: 28). Uzun yıllardır pazarlama ve tüketici araştırmaları literatüründe, tüketici deneyimi ve hazcı tüketim konuları ele alınarak incelenmektedir. Deneyim kavramının ortaya çıkmasının temel sebebi olarak, pazarlamanın geleneksel fayda ve yararlarının artık tüketicilerin ihtiyaçlarını karşılayabilecek nitelikte olmaması olarak gösterilebilir. Günümüzde bilgi teknolojilerinin her yerde bulunması ve kullanılması, markanın üstünlüğü, tüketici refah düzeyinin ve bilgisinin artması gibi nedenlerle, tüketici taleplerindeki değişimler, hizmet sektöründe rekabetin artması, aynı zamanda birçok yerde mevcut olan iletişimin ve eğlencenin iç içe geçmesi gibi gelişmeler deneyim kavramının öneminin anlaşılmasına neden olmuştur (Karadayı ve Alan, 2014: 204).

Deneyim, deneyimsel pazarlamanın temel öğesidir. Özel alanlar, atmosfer ve yeni ortamlar gibi farklı uyaranlar yaratmayı amaçlamaktadır. Bu şekilde tüketicilerin bu uyaranlara cevap vermesi, aktif satın alma davranışı göstermesi, deneyim kazanması ve zevk, eğlence gibi farklı duygular kazanması beklenmektedir. $\mathrm{Bu}$ noktada, ürün/hizmetin kendisi, ürün/hizmet sunan işletme, ürün/hizmet tarafından sağlanan fayda ve deneyimsel pazarlamada ürün/hizmetin marka adı için ortamın yaşanması da önemlidir (Alagöz ve Ekici, 2014: 501).

Holbrook ve Hirschman (1982), Pine ve Gilmore (1998) ile Schmitt (1999) deneyim kavramını kullanan kişiler olarak literatürde dikkat çekmektedirler (Atay ve Çeti, 2018: 557). Deneyim kavramı tüketici davranışı literatürüne 1982 yılında Holbrook ve Hirschman tarafından kazandırılmıştır. Joseph Pine ve James Gilmore tarafından 1998 yılında deneyim ekonomisi kavramı ortaya atılmıştır. Deneyimsel 
pazarlamanın gelişimi kesin olarak ilk kez Pine ve Gilmore aracılığıyla “Welcome to the Experıence Economy" adlı makalede 1998 yılında ortaya konmuştur. Daha sonra ise 1999 yılında Schmitt deneyimsel pazarlama kavramını yeni pazarlama anlayışına kazandırmıştır (Yeşilot ve Dal, 2019: 266). Holbrook ve Hirschman (1982) yapmış oldukları çalışmalarında tüketimin önemli deneyimsel yönlerinin tanınmasını tartışmaktadırlar. Spesifik olarak, tipik tüketici davranışı değişkenlerini temsil etmek için genel bir çerçeve oluşturulur. Bu çalışmada tüketim deneyimi fantaziler, duygular ve eğlencenin peşinde koşan bir olgu olarak görülmektedir (Holbrook ve Hirschman, 1982: 132).

Pine ve Gilmore (1998) yapmış oldukları çalışmada deneyim ekonomisine değinmişlerdir. Bu çalışmaya göre ekonomistler genellikle hizmetlerle ilgili deneyimleri bir araya getirmişlerdir. Fakat hizmetler mallardan nasıl ki farklı bir ekonomik sunu ise deneyimlerde hizmetlerden farklı bir ekonomik sunudur. Bu dördüncü ekonomik teklif tanımlanabilir ve açıklanabilir çünkü tüketiciler tartışmasız deneyimler arzular ve gittikçe daha fazla işletme bunları açıkça tasarlayıp tanıtarak yanit verir. Hizmetler, onlardan önceki mallar gibi, giderek metalaşan deneyimler haline geldikçe, ekonomik değerin ilerlemesi dediğimiz bir sonraki adım olarak ortaya çıkmıştır (Pine ve Gilmore; 1998: 97). Pine ve Gilmore (2001)’e göre birisi iyi bir şey aldığında, elle tutulur bir şey alır; bir hizmet satın aldığında, kendi adına gerçekleştirilen bir dizi maddi olmayan faaliyet satın alır. Ancak bir deneyim satın aldığında, bir şirketin kendisini kişisel bir şekilde meşgul etmek için sahneye koyduğu unutulmaz bir olay için ödeme yapar (Pine ve Gilmore, 2001: 4). Pazarlamanın amacı satışları gereksiz kılmaktır. Deneyimlerin amacı pazarlamayı gereksiz kılmaktır (Pine ve Gilmore, 2002: 5).

İç ve dış koşullardaki değişiklikler, bir şirketin sürekli olarak dinamik olmasını ve mümkün olan her fırsattan yararlanmak ve her değişiklikle yüzleşmek için durmaksızın hazırlıklı olmasını gerektirir. Bir şirketin başarısı, müşterinin ürünlerine verdiği yanıtlarla büyük ölçüde bozulur ve şirketin çeşitli ürünler yaratarak sürekli yaratıcı ve proaktif olmasını gerektirir (Khotimah, Sucherly, Sari ve Kaltum, 2016: 431). Deneyimsel pazarlama, yükselen bir pazarlama yönetimi felsefesidir. Bu konsepti benimseyen işletmeler, tüketicilerine unutulmaz bir deneyim sunmak için kendilerini 
zorlayacaklardır (Tsaur, Chih ve Wang, 2007: 48). Artan sayıda insan, pazar sunularında sıklıkla buldukları anlam, mutluluk, hisler, yeni tatmin biçimleri ve temel değerleri aramaktadır. Deneyim pazarlaması, pazarlama ve işletmeye yeni bir yaklaşımdır. Geleneksel pazarlamaya kıyasla yenilikçi ve yaratıcı bir yaklaşımdır ve gelecek yıllarda önemli bir büyüme alanı olacaktır. Zaten 1999'da Schmitt, geleneksel özellik ve fayda pazarlamasını deneyimsel pazarlama ile değiştirecek bir devrimin ortasında olduğumuzu açıklamıştır (Same ve Larimo, 2012: 480).

Schmitt (1999) yapmış olduğu “Deneyimsel Pazarlama" başlıklı çalışmasında deneyimsel pazarlamanın önemli bir kavramı olarak 5 tane stratejik deneyimsel modülü ortaya koymuştur. Bu beş modül duyusal, duygusal, düşünsel, davranışsal ve ilişkisel olmak üzere 5 başlık altında incelenmektedir (Schmitt, 1999: 60).

Duyusal modül veya duyusal pazarlama görme, işitme, dokunma, tat ve koku ile duyusal deneyimler yaratmak amaciyla duyulara hitap eder. Duyusal pazarlama şirketleri ve ürünleri farklılaştırmak, müşterileri motive etmek ve ürünlere değer katmak için kullanılabilir. Duygusal pazarlama, bir markaya bağlı hafif olumlu ruh halinden güçlü sevinç ve gurur duygularına kadar değişen duygusal deneyimler yaratmak amacıyla müşterilerin iç duygularına ve duygularına hitap eder. Duygusal pazarlamanın çalışması için gerekli olan, belirli duyguları hangi uyaranın tetikleyebileceğinin çok iyi anlaşılmasıdır. Düşünsel pazarlama, müşterileri yaratıcı bir şekilde meşgul eden bilişsel, problem çözme deneyimleri yaratmak amacıyla akla hitap eder. Davranıssal pazarlama, fiziksel davranışları, yaşam tarzlarını ve etkileşimleri hedefler. Davranışsal pazarlama, fiziksel deneyimlerini hedefleyerek, onlara bir şeyler yapmanın alternatif yollarını, alternatif yaşam tarzlarını ve etkileşimleri göstererek müşterilerin hayatlarını zenginleştirir. İlişkisel pazarlama, bireylerin sosyal bağlamın bir parçası olma isteklerini dikkate alarak deneyimler yaratır. İlişkisel pazarlama duyusal, duygusal, düşünsel ve davranışsal pazarlamanın özelliklerini içerir (Schmitt, 1999: 61-62; Schmitt, 2010: 68).

Pine ve Gilmore (1998) yapmış oldukları çalışmada deneyime ait 4 boyutu ortaya koymuşlardır. Bu boyutlar eğlence, eğitim, kaçış ve estetiktir (Pine ve Gilmore, 1998: 102). Eğlence olarak düşündüğümüz deneyimler; bir şova gitmek gibi, genellikle 
etkinlikle bağlantılarının özümsemeyi içereceği pasif bir şekilde katılan müşterileri içerir. Turizm ve otelcilik alanındaki pazarlamacılar için, bu boyutun anahtarı onu daha bütünsel olarak uygulamak, yani eğlenceyi hemen deneyim dişındaki alanlara dahil etmek olabilir (Williams, 2006: 488). Bir derse katılmak, bir kayak dersi almak gibi eğitim etkinlikleri daha aktif katılımı gerektirir. Katılımcılar işin içine dahil olmaktan daha çok özümseme aşamasındadırlar (Pine ve Gilmore, 1998: 102). Genel olarak, turistler ziyaret ettikleri destinasyonlardaki eğitim deneyimleri yoluyla genel veya özel becerilerini ve bilgilerini arttırırlar (Oh, Fiore ve Jeoung, 2007: 121). Estetik deneyim, pasif katılım ve sarmalanma alanında yer alır. Estetik bir ürünün tat alma, koku, dokunma, duyma ve görme organlarına yönelik olmasıdır. Merak duygusu estetik deneyimde önemli bir unsurdur. Örneğin peribacalarının arasında olmak estetik deneyime örnektir (Deligöz, 2014:76). Kaçış deneyimi eğlence deneyiminin tam tersidir; örneğin, kaçışçı bir deneyim bir gösteriye katılmak ya da bir orkestrada oynamak olacaktır (Yuan ve $\mathrm{Wu}, 2008$ : 390). Kaçış deneyimi, Sarmalanma ve aktif katılım gerektirir. Kaçış deneyimlerine katılan turistler sadece belirli bir yere gitmekle kalmaz, aynı zamanda zamanlarına layık faaliyetlere katılırlar. Kaçış deneyimi, turistin gerçek veya sanal ortamdaki gerçek performansları veya olayları etkilemesini gerektirir. Genel olarak turizm, sıradanları deneyimledikten sonra insanların günlük yaşamlarından kaçma ve rutine dönme yoludur (Oh, Fiore ve Jeoung, 2007: 121).

Turizm deneyimi turizm olayı içerisine katılan bireyler için oldukça önemli bir konudur. Turistler gittikleri destinasyonlarda konakladıkları otellerde, yemek yedikleri restoranlarda, ulaşım sağladıkları ulaştırma işletmelerinde, eğlendikleri eğlence işletmelerinde vb. farklı deneyimler aramaktadırlar. Turizm işletmeleri de yeni müşteriler elde etmek ya da mevcut müşterilerinin devamlılı̆̆ını sağlamak adına müşterilerine farklı deneyimler sunmaktadırlar. Yerli ve yabancı literatür tarandığında turizm işletmelerinde deneyimsel pazarlama ile ilgili farklı çalışmaların gerçekleştiği görülmektedir. Bu çalışmalar gerek müşteriler gerekse işletme çalışanları üzerinde gerçekleştirilmiştir.

Akyıldız (2010) yapmış olduğu çalışmada 2009 Rock'n Coke festivalinde boş zaman pazarlamasında deneyimsel boyutları incelemiştir. Çalışmada festivale katılanların deneyimleri sosyo ilişki, yaşam tarzı, duygulanım, duyumsama olmak 
üzere 4 farklı boyutta incelenmiştir. Çalışma so nucunda boyutların hoşlanma, tavsiye etme niyeti ve memnuniyet durumu üzerinde olumlu bir etkiye sahip olduğu tespit edilmiştir.

Kara ve Çiçek (2015) tarafından deneyimsel pazarlamanın satın alma karar sürecine etkisi termal turizm sektöründe incelenmiştir. Çalışmada deneyimsel modüllerin satın alma kararı üzerindeki etkisi incelenmiş ve termal turizm işletmelerinin düşünsel ve duygusal deneyimlere yönelik yaptıkları faaliyetlerin satın alma kararını etkilediği tespit edilmiştir.

Atay ve Çeti (2018) tarafından gerçekleştirilen çalışmada botellerde konaklayan turistlerin deneyimleri belirlenmiştir. İçerik analizi ile gerçekleştirilen çalışma sonucunda turistlerin botel temasına bağlı olarak botelin manzarası, konumu ve tasarımından etkilendikleri ve temaya bağlı elde ettikleri deneyimleri olumlu bir şekilde değerlendirdikleri tesspit edilmiştir.

Çeltek (2010) yapmış olduğu çalışmada deneyimsel pazarlama unsurlarını otel bakış açısı ile değerlendirmiştir. Çalışmada deneyim boyutları, deneyim türleri ve deneyim sağlayıcılar otel yöneticileri tarafından verilen cevaplar ile belirlenmiştir.

Taşkıran ve Kızılırmak (2019) deneyimsel pazarlama kapsamında sanal turların müze ziyaretlerine etkisini incelemişlerdir. Çalışma sonucunda Taşkıran ve Kızılırmak gerçek ziyaretin sanal tura göre daha etkili olduğu, sanal deneyimin heyecan ve istek yaratacak güçte bir çekiciliği olmadığı sonucuna varmışlardır.

Tunç (2017) restoran müşterileri üzerine yapmış olduğu çalışmada deneyimsel pazarlamanın müşteri memnuniyeti üzerine etkisini araştırmıştır. Çalışmada deneyimsel pazarlama yöntemlerinin müşteri memnuniyeti ve sadakati üzerinde olumlu bir etkisinin olduğunu tespit etmiştir.

Uygur ve Doğan (2013) tarafından restoran müşterileri üzerinde gerçekleştirilen çalışmada yaşatılan deneyimlerin algısal ve faaliyetsel deneyimler boyutunda olduğu ve restoranların, hissel, düşünsel ve ilişkisel boyutta da müşterilerine deneyim yaşatma hususunda çalışmalar yapması gerektiği tespit edilmiştir. 
Yapraklı ve Keser (2016) tarafından nostaljik ve fast food restoran müşterileri üzerine gerçekleştirilen deneyimsel pazarlama ve deneyimsel değerin müşteri memnuniyeti ve müşteri sadakati üzerine etkisinin tespit edildiği çalışmada deyimsel pazarlamanın deneyimsel değer üzerinde ve bununla birlikte hem deneyimsel pazarlamanın hem de deneyimsel değerin müşteri memnuniyeti ve müşteri sadakati üzerinde anlamlı ve pozitif bir etkiye sahip olduğu tespit edilmiştir.

Deligöz (2014) tarafından 2 farklı kahve işletmesi müşterileri üzerine gerçekleştirilen ve deneyimsel pazrlama uygulamalarının marka tercihi üzerine etkisinin belirlendiği çalışmada deneyimsel pazarlama boyutlarının deneyimsel memnuniyet ve deneyimsel bağlılık üzerinde etkisi olduğu sonucuna varılmıştır.

Coşkunoğlu (2019) tarafından konaklama işletmelerinde çalışanların otel özelliklerine göre deneyimsel pazarlama algısının tespit edildiği çalışmada işletmelerin farklı özelliklerine göre deneyim türü, deneyim boyutları ve deneyim sağlayıcıların bazı boyutlarında farklılıkların olduğu tespit edilmiştir.

Ihtiyar, Barut ve Ihtiyar (2018) tarafından gerçekleştirilen çalışmada deneyimsel pazarlama modüllerinin, hizmet kalitesinin ve sosyal muhakemenin deneyimsel değerleri üzerindeki etkisi kahve işletmeleri müşterileri üzerinde incelenmektir. Çalışma sonucunda bazı deneyimsel modüllerin ve hizmet kalitesinin deneyimsel değerler üzerinde olumlu etkiye sahip olduğunu ortaya konmuştur.

Mehmetoğlu ve Engen (2011) tarafından gerçekleştirilen çalışmada Pine ve Gilmore' un deneyim ekonomisi kavramı ve boyutları bir festival ve bir müzeyi ziyaret eden turistlerin katılımı ile belirlenmiştir. Çalışma sonuçlarına göre, farklı bağlamlarda ziyaretçilerin genel memnuniyetini etkileyen farklı deneyimsel boyutların olduğu ortaya konmuştur.

Lin (2006) tarafından Tayvan Kaplica Otellerinde Deneyimsel Pazarlama Stratejisi ve Konukların Boş Zaman Davranışı Arasındaki İlişkinin İncelenmesi üzerine yapılan çalışmada, misafirlerin deneyimsel pazarlama algılarının sadakat davranışı üzerinde doğrudan bir etkisi olmasına rağmen, misafirlerin deneyimsel pazarlama ve sadakat davranışı algıları arasındaki ilişkiye algılanan deneyimsel değer ve memnuniyetin güçlü bir şekilde aracılık ettiği sonucuna ulaşılmıştır. 
Oh, Fiore ve Jeoung (2007) Deneyim Ekonomisi Kavramının Ölçülmesi: Turizm Uygulamaları başlıklı çalışmalarında turizm işletmelerinde uygulanabilecekPine ve Gilmore tarafından ortaya atılan deneyim boyutlarına ilişkin ölçek gelişitirmişlerdir.

Lee ve Chang (2012) yaptıkları çalışmada Tayvan'daki şarap turistlerinin deneyimsel pazarlama, etkinlik katılımı, memnuniyet ve sadakat niyetlerinin gizli değişkenlerini kullanan bir davranış modelini değerlendirmişlerdir. Çalışmada, deneyimsel pazarlama deneyimi, aktivite katılımı ve memnuniyetin şarap turistlerinin sadakat niyetlerini önemli ölçüde etkilediğini göstermektedir. Memnuniyet, davranışsal modelde arabulucu rol oynamıştır.

Oral ve Yetim (2015) deneyimsel değer, tüketici tatmini ve tüketici sadakati arasındaki ilişkinin belirlemeye yönelik gerçekleştirdikleri çalışmada tur operatörlerinin uzakdoğulu turistler sundukları deneyimsel değer boyutlarının bazılarının bu turistlerin tatmin ve sadakatini etkilediğini ortaya koymuşlardır.

Garcia, Galindo ve Suarez (2018) tarafından yapılan çalışma, çevrimiçi deneyimsel pazarlama (bilgi arama ve rezervasyon içeren satın alma sürecinde) ile çevrimdışı deneyimsel pazarlama (konaklama sırasında) ile otel marka değeri arasındaki ilişkiyi ölçmeyi amaçlamaktadır. Çalışma sonuçlarına göre çevrimiçi konaklama sürecinin aksine, otel konaklaması sırasındaki deneyimin otel markası değeri üzerinde etkili olduğunu göstermektedir. Bununla birlikte, çevrimiçi deneyim, otel konaklama deneyimi üzerinde önemli bir etkiye sahiptir.

Yeh, Chen ve Chen (2019) tarafından müzede gerçekleştirilen çalışmada deneyimsel pazarlamanın müşteri memnuniyeti üzerine pozitif etkisi olduğu ortaya konmuştur.

Lin (2019) tarafından gerçekleştirilen “Ekoturizmde Deneyimsel Pazarlamanın Deneyim Değeri ve Müşteri Memnuniyeti Üzerine Etkileri" başlıklı çalışmada araştırma sonuçları deneyimsel pazarlama ve deneyim değeri, deneyim değeri ve müşteri memnuniyeti ile deneyimsel pazarlama ve müşteri memnuniyeti arasında pozitif ilişkiler olduğunu göstermiştir. 


\section{ARAŞTIRMANIN AMACI VE ÖNEMI}

Günümüz tüketicileri gelişen bilgi teknolojileri ile birlikte satın alacakları mal/hizmetler için satın alma aşamalarından bilgi arama aşamasına daha fazla dikkat etmektedirler. Tüketiciler satın alacakları mal/hizmet ile ilgili bilgi ararlarken hangi mal/hizmeti satın alırlarsa daha fazla fayda sağlayabileceklerini araştırmaktadırlar. Tüketiciler için elde edecekleri faydaların yanında yaşayabilecekleri yeni ve farklı deneyimlerde önemli bir konu halini almıştır. Tüketiciler satın aldıkları ürün ya da hizmetten sağladıkları üst düzey fayda ve yaşadıkları farklı deneyimlerle birlikte tatmin olmaktadırlar. Özellikle konaklama işletmelerinde turistlerin yaşadıkları olumlu deneyimler turistler için daha fazla önemli bir hal almaktadır. Tujristlerin kısa süreli tatillerinde yaşayabildikleri farklı deneyimler onların tatil sonrası da bu deneyimleri hatırlamalarına yol açabilmektedir. Turistlerin yaşadıkları hatırlanabilir olumlu deneyimler turistlerin bir sonraki tatil planları sırasında tekrar göz önüne gelip turistlerin aynı otel işletmesini tekrar seçmelerine yol açabilmektedir. Aynı zamanda ağızdan ağıza iletişimin de önemli bir faktör olduğu otel işletmelerinde turistler yaşadıkları olumlu deneyimler ile birlikte tatillerini geçirdikleri otelin ama elektronik ortamda ama birebir ilişkilerde doğal tanıtım elçileri olacaklardır.

Günümüz işletmeleri rekabet avantajı sağlamak adına klasik pazarlama stratejileri ile birlikte modern pazarlama stratejilerinide etkin olarak kullanmaktadırlar. Bu pazarlama stratejilerinden önemli bir taneside işletmelerin günmüzde sıklıkla kullandıkları deneyimsel pazarlamadır. İşletmeler deneyimsel pazarlama yolu ile müşterilerinin taminini ve sadakatini sağlamaya çalışmaktadırlar. Böylece hem mevcut müşterilerini ellerinde tutabilmekte hem de yeni müşteriler elde edebilmektedirler. Otel işletmeleri de konaklamak için kendi tesislerini tercih eden müşterilerine yaşattıkları farklı deneyimler sayesinde onları devamlı müşteri haline getirme şansları oldukça yüksektir. Otel işletmeleri günümüzde müşterilerine otele girişlerinden çıkışlarına kadar farklı departmanlarda farklı deneyimler sunmaktadırlar. Turistler bu farklı deneyimleri duyusal, duygusal, düşünsel, davranışsal ve ilişkisel olmak üzere 5 modül ve eğlence, eğitim, estetik ve kaçış olmak üzere 4 boyutta yaşamaktadırlar. Turistlerin bu modül ve boyutlarda yaşadıkları deneyimler için otel yönetiminin de bu doğrultuda çalışmalar yapması önemli bir 
konudur. Otel yönetiminin bu boyut ve modüllerdeki özelliklere dikkat etmeleri turistlerin otel ziyaretlerinde farklı deneyimleri yaşayabilmesi adına önem taşımaktadır.

$\mathrm{Bu}$ bağlamda bu çalışmanın temel amacı otel yöneticileri bakış açısıyla deneyimsel pazarlama modüllerinin ve boyutlarının incelenmesidir. Bu temel amaç doğrultusunda otel özelliklerine göre deneyim modülleri ve deneyim boyutları arasındaki farklılıkları ortaya koymak çalışmanın alt amacını oluşturmaktadır.

\section{YÖNTEM}

$\mathrm{Bu}$ çalışmada nicel araştırma yöntemlerinden ilişkisel tarama modeli kullanılmıştır. Bu çalışmada veri toplama tekniği olarak anketten yararlanılmıştır Anket sorularının tamamı Çeltek (2010) tarafından gerçekleştirilen "Deneyimsel Pazarlama Unsurlarının Otellerin Bakış Açısı İle Değerlendirilmesi: Türkiye' deki 4 ve 5 Yıldızlı Otel İşletmelerinde Bir Uygulama" başlıklı Doktora tezinden alınmıştır. Çeltek (2010) anket sorularını oluştururken deneyim boyutları ile ilgili olan ifadeler Haemoon Oh, Ann Marie Fiore ve Miyoung Jeoung'un “Measuring Experience Economy Concepts: Tourism Applications" başlıkl Journal of Travel Research 2007; 46; 119’da yayınlanan makalesindeki önermeleri çevirerek oluşturmuştur. Deneyim modülleri ile ilgili ifadeleri ise Lin, Kuo-Ming, An Examination Of The Relationship Between Experiential Marketing Strategy And Guests' Leisure Behavior In Taiwan Hot-Spring Hotels, Thesis For The Degree Of Doctor Of Sport Management United States Sports Academy, 2006'dan yararlanarak oluşturmuştur. Bu ölçekler aynı zamanda Coşkunoğlu (2019) "Konaklama İşletmelerinde Çallışanların Otel Özelliklerine Göre Deneyimsel Pazarlama Algısı:Trabzon İline Yönelik Bir Araştırma" adlı çalışmada da Çeltek (2010)'den yararlanılarak kullanılmıştır. Oluşturulan anket iki temel bölümden oluşmaktadır. Anketin ilk bölümünde otel işletmelerinin temel özelliklerini belirlemeye yönelik sorular yer almaktadır. Anketin ikinci bölümünde ise 22 ifade ve eğitim, eğlence, estetik ve kaçış olmak üzere 4 boyuttan oluşan, yöneticilerin deneyim boyutlarına yönelik bakış açılarını belirlemeye yönelik ölçek yer almaktadır. Bu sorular 5’li likert ölçeği şeklinde hazırlanmıştır (Hiç katılmıyorumkatılmıyorum-Ne katılıyorum Ne katılmıyorum-katılıyorum-kesinlikle katılıyorum). 
Anketin üçüncü bölümünde ise 19 ifade ve duyusal, duygusal, düşünsel, davranışsal ve ilişkisel olmak üzere 5 boyuttan oluşan, yöneticilerin deneyim modüllerine yönelik bakış açılarını belirlemeye yönelik ölçek yer almaktadır. Bu sorular 5'li likert ölçeği şeklinde hazırlanmıştır (Hiç katılmıyorum-katılmıyorum-Ne katılıyorum $\mathrm{Ne}$ katılmıyorum-katılıyorum-kesinlikle katılıyorum). Çalışmada 32 yöneticiden veri toplandığından çalışmada tekrar bir faktör analizi gerçekleştirilmemiş ve analizler orjinal ölçeklere sadık kalınarak boyut ortalamalarına göre analizler gerçekleştirilmiştir. Katılımcı sayıları az olduğundan otel işletmelerinin farklı özelliklerine göre deneyim boyutları ve deneyim modüllerine bakış açılarındaki farklılıkları ortaya koymak için parametrik olmayan testler kullanılmıştır.

Çalışma Kuşadası' nda faaliyette bulunan 4 ve 5 yıldızlı otel işletmelerinde 2019 yılı Aralık ayında gerçekleştirlmiştir. Bu nedenle etik kurul izin belgesine gerek yoktur. Anketler bu işletmelerde özellikle pazarlamadan doğrudan sorumlu yöneticiler ile gerçekleştirilmiştir. Aydın İl Kültür ve Turizm Müdürlüğü'nün internet sayfasında Kuşadası'nda işletme belgeli olarak faaliyette bulunan 13 tane 5 yıldızlı 24 tanede 4 yıldızlı otel işletmesi bulunmaktadır. Çalışmada öncelikle toplam 37 işletmenin hepsine ulaşılması hedeflenmiştir. Ancak bazı işletmeler yöneticilerinin anket zamanında bulunmaması, ankete katılmak istememeleri gibi farklı sebeplerle çalışmaya katılmamışlardır. Toplamda anket çalışmasına 32 işletme olumlu yanıt vermiş ve bu işletmelerin katılımları sağlanmıştır.

\section{ARAŞTIRMA BULGULARI}

Araştırma bulguları bölümünde öncelikle otel işletmelerine ait özelliklerin frekans dağılımları, katılımcıların sorulara verdikleri cevapların frekans dağılımları ve hipotez testleri yer almaktadir.

\subsection{Otel İşletmelerine Ait Özellikler}

Otel işletmelerinin büyük çoğunluğu 4 yıldızlı otel işletmelerinden oluşmaktadır $(\% 68,8)$. 
Tablo 1. Otel İşletmelerine Ait Özellikler

\begin{tabular}{|c|c|c|c|}
\hline & & Frekans & Yüzde \\
\hline \multirow{2}{*}{ Yıldız Sayısı } & 4 Yildizli & 22 & 68,8 \\
\hline & 5 yıldızlı & 10 & 31,3 \\
\hline \multirow{2}{*}{ Faaliyet Durumu } & Devamlı & 7 & 21,9 \\
\hline & Mevsimlik & 25 & 78,1 \\
\hline \multirow{4}{*}{ Otel Faaliyet Süresi } & 10 Yildan Az & 8 & 25,1 \\
\hline & $11-15$ & 9 & 28,1 \\
\hline & $16-20$ & 5 & 15,6 \\
\hline & 21 ve üzeri & 10 & 31,2 \\
\hline \multirow{3}{*}{ Otel Kapasitesi } & 150 Odanın Altı & 14 & 43,8 \\
\hline & $150-299$ & 10 & 31,3 \\
\hline & $300-600$ & 8 & 25,0 \\
\hline
\end{tabular}

Çalışmaya katılan kişilerin çalıştıkları otellerin büyük bölümü 21 yıl ve üzeri hizmet vermektedir $(\% 31,3)$. Otellerin büyük bölümü mevsimlik otel işletmesi olarak hizmet vermektedir $(\% 78,1)$. Otel işletmeleri kapasite açısından incelendiğinde işletmelerin büyük çoğunuğu 150 odanın altında kapasiteye sahiptir $(\% 43,8)$.

\subsection{Deneyim Boyutlarına Ait Ortalama Standart Sapmalar}

Deneyim boyutlarına ait ortalama ve standart sapmalar tablo 2'de yer almaktadır. Boyutlar ortalamalar açısından incelendiğinde en düşük ortalamaya eğitim boyutu $(3,62)$ sahiptir. Eğitim boyutu içerisinde ise “Çoğu misafirimiz yeni bir şeyler öğrenebildiği için otelimize tekrar gelmektedir." İfadesi en düşük ortalamaya $(3,50)$ sahiptir. 
Tablo 2. Deneyim Boyutlarına Ait Ortalama ve Standart Sapma

\begin{tabular}{|c|c|c|c|c|c|}
\hline & & 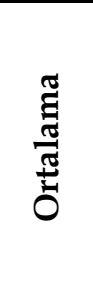 & 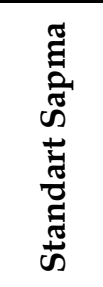 & 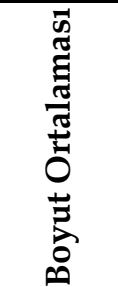 & 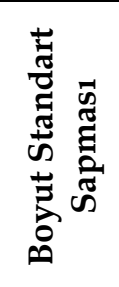 \\
\hline \multirow{5}{*}{ 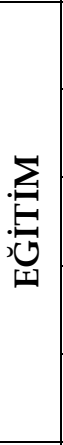 } & $\begin{array}{l}\text { Otelinizde müşterilerin yeni bir şeyler öğrenebilmesine } \\
\text { yardımcı olacak aktiviteler tasarlanmıştır. }\end{array}$ & 3,72 & 0,991 & \multirow{5}{*}{3,6250} & \multirow{5}{*}{,95275 } \\
\hline & $\begin{array}{l}\text { Otelimizde müşteriler için eğitim içerikli aktiviteler, } \\
\text { deneyimler oluşturulmuştur. }\end{array}$ & 3,63 & 0,976 & & \\
\hline & 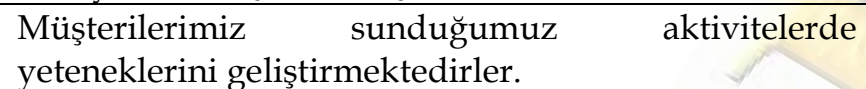 & 3,63 & 1,238 & & \\
\hline & $\begin{array}{l}\text { Çoğu misafirimiz yeni bir şseyler öğrenebildiği için } \\
\text { otelimize tekrar gelmektedir. }\end{array}$ & 3,50 & 1,218 & & \\
\hline & $\begin{array}{l}\text { İşletmemizin bir teması olarak müşsterilerimize } \\
\text { fırsatları öğrenme yaratılmaktadır/geliștirilmektedir. }\end{array}$ & 3,66 & 1,208 & & \\
\hline \multirow{6}{*}{ 当 } & $\begin{array}{l}\text { Otelimiz müşterilerin beş duyusuna (tatma, görme, } \\
\text { dokunma ,koklama, duyma) hitap edecek şekilde } \\
\text { tasarlanmiştır. }\end{array}$ & 4,22 & 0,792 & \multirow{6}{*}{4,2396} & \multirow{6}{*}{ 67989, } \\
\hline & $\begin{array}{l}\text { Otelimizin mimari tasarımında ve dekorasyonunda } \\
\text { estetik unsurlara önem verilmiştir. }\end{array}$ & 4,25 & 0,916 & & \\
\hline & $\begin{array}{l}\text { Otelimizin temasında estetik unsurlar ve sanat ön } \\
\text { plana çıkmaktadır. }\end{array}$ & 4,16 & 0,847 & & \\
\hline & $\begin{array}{l}\text { Otelimizin müssteri odalarında tasarım ve dekorasyon } \\
\text { ön plana çıkmaktadır. }\end{array}$ & 4,09 & 0,893 & & \\
\hline & $\begin{array}{l}\text { Otelimizin diğer otellerden farklı ve ilgi çekici bir } \\
\text { tasarımı vardır. }\end{array}$ & 4,25 & 0,88 & & \\
\hline & $\begin{array}{l}\text { Restoranlarımızda sunulan yemeklerin görüntüsü ve } \\
\text { lezzetine dikkat edilmektedir. }\end{array}$ & 4,47 & 0,671 & & \\
\hline \multirow{6}{*}{ 崔 } & $\begin{array}{l}\text { Müşterilerimizin otelde konaklarken günlük hayattaki } \\
\text { sıkıntılarından tamamen uzaklaşmasına çaba } \\
\text { gösterilmektedir. }\end{array}$ & 4,44 & 0,716 & \multirow{6}{*}{4,1927} & \multirow{6}{*}{,77611 } \\
\hline & $\begin{array}{l}\text { Otelimizde müsterilerin aktif olarak katılabilecekleri } \\
\text { aktiviteler eğlenceli bulunmaktadır. }\end{array}$ & 4,16 & 0,987 & & \\
\hline & $\begin{array}{l}\text { Otelimizde müsterilerin fiziksel } \\
\text { yapabileceği imkânlarımız bulunmaktadır. }\end{array}$ & 4,13 & 1,185 & & \\
\hline & Otelimizin temasında eğlence ön plana çıkmaktadır. & 3,69 & 1,355 & & \\
\hline & $\begin{array}{l}\text { Otelimiz müşterilerin gerçekten kendilerini tamamen } \\
\text { farklı bir yer ve zamanda hissetmelerini sağlamaktadır. }\end{array}$ & 4,41 & 0,665 & & \\
\hline & $\begin{array}{l}\text { Müşterilerimizin otelimizde aktif olarak farklı bir } \\
\text { ortamda hissetmelerine çaba gösterilmektedir. }\end{array}$ & 4,34 & 0,902 & & \\
\hline \multirow{5}{*}{ 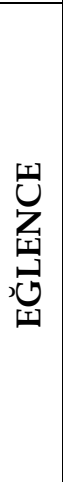 } & $\begin{array}{l}\text { Otelimiz müşterilerin dinlenebildiği ve eğlenebildiği } \\
\text { bir ortam sağlayacak şekilde tasarlanmıştır. }\end{array}$ & 4,31 & 0,738 & \multirow{5}{*}{4,0063} & \multirow{5}{*}{ 93600 } \\
\hline & $\begin{array}{l}\text { Otelimizde müşterilere } \\
\begin{array}{l}\text { kenakladıkları sürece } \\
\text { eğlenebilecekleri } \\
\text { çalışılmaktadır. }\end{array}\end{array}$ & 4,00 & 1,136 & & \\
\hline & $\begin{array}{l}\text { Otelimizin eğlenme imkanlarından dolayı çoğu } \\
\text { müşterimiz otelimizde konaklamayı seçmektedir. }\end{array}$ & 3,84 & 1,167 & & \\
\hline & $\begin{array}{l}\text { Otelimizdeki aktiviteler müşterilerin izlerken } \\
\text { eğlenebileceği şekilde tasarlanmıştır. }\end{array}$ & 3,97 & 1,15 & & \\
\hline & $\begin{array}{l}\text { Otelimizde müşterilerimizin eğlenmeleri için özel } \\
\text { animasyonlar düzenlenmektedir. }\end{array}$ & 3,91 & 1,422 & & \\
\hline
\end{tabular}


Deneyim boyutları incelendiğinde katılımcıların vermiş oldukları cevaplara göre en yüksek ortalamaya estetik boyutu $(4,2396)$ sahiptir. Estetik boyutu içerisinde ise "Restoranlarımızda sunulan yemeklerin görüntüsü ve lezzetine dikkat edilmektedir." İfadesi en yüksek ortalamaya $(4,47)$ sahiptir. İfadelere verilen yantlar genel olarak incelendiğinde ortalamaların 3,50 ve üzerinde olması genel anlamda iyi olarak görünsede işletmelerin deneyimsel pazarlama konusuna daha fazla önem vermeleri gerekmektedir.

\subsection{Deneyim Modüllerine Ait Ortalama Standart Sapmalar}

Deneyim modüllerine ait ortalama ve standart sapmalar tablo 3'de yer almaktadır. Modüller ortalamalar açısından incelendiğinde en düşük ortalamaya düşünsel modülü $(3,75)$ sahiptir. Düşünsel modül içerisinde ise "Otelimizde müşteriler için spor kurslarının olmasına özen gösterilmektedir.." İfadesi en düşük ortalamaya $(3,47)$ sahiptir.

Deneyim modülleri incelendiğinde katılımcıların vermiş oldukları cevaplara göre en yüksek ortalamaya duygusal modül $(4,2344)$ sahiptir. Duygusal modül içerisinde ise "Otelimiz müşterilerin huzurlu olabileceği bir ortam sağlamaya çalışır." İfadesi en yüksek ortalamaya $(4,28)$ sahiptir. İfadelere verilen yantlar genel olarak incelendiğinde ortalamaların 3,47 ve üzerinde olması genel anlamda deneyim boyutlarında olduğu gibi iyi olarak görünsede işletmelerin deneyim modülleri konusuna daha fazla önem vermeleri gerekmektedir. 
Tablo 3. Deneyim Modüllerine Ait Ortalama ve Standart Sapma

\begin{tabular}{|c|c|c|c|c|c|}
\hline & & 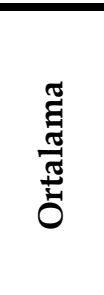 & 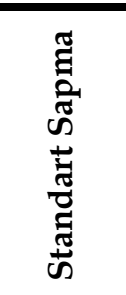 & 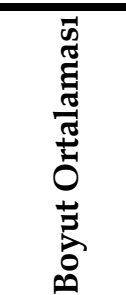 & 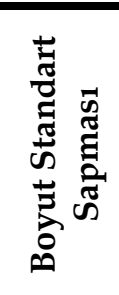 \\
\hline \multirow{6}{*}{ 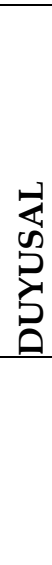 } & $\begin{array}{l}\text { Otelimizin mönüsü farklı tatlar ve ülke yemeklerini } \\
\text { içermektedir. }\end{array}$ & 4,19 & 896 & \multirow{4}{*}{4,0469} & \multirow{4}{*}{ 77885 } \\
\hline & $\begin{array}{l}\text { Otelimizde farklı temaları içeren odaların bulunması } \\
\text { önemlidir. }\end{array}$ & 3,66 & 1,125 & & \\
\hline & $\begin{array}{l}\text { Otelimizde otel ile uyumlu müziklerin kullanılmasına } \\
\text { dikkat edilir. }\end{array}$ & 4,19 & 780 & & \\
\hline & $\begin{array}{l}\text { Otelimizde odalarda ve lobide güzel kokunun } \\
\text { kullanılmasına dikkat edilir. }\end{array}$ & 4,16 & ,884 & & \\
\hline & $\begin{array}{l}\begin{array}{l}\text { Reklamlarda müşterinin otelde } \\
\text { hissedeceğini } \\
\text { vurgulayan } \\
\text { kullanılmaktadır. }\end{array} \\
\text { mesajlar/görüntüler }\end{array}$ & 4,25 &, 842 & \multirow{4}{*}{4,2344} & \multirow{4}{*}{,83506 } \\
\hline & $\begin{array}{l}\text { Otelimiz müssterilere mutlu olabileceği bir ortam } \\
\text { sağlamaya dikkat eder. }\end{array}$ & 4,25 & ,916 & & \\
\hline \multirow{2}{*}{ 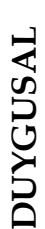 } & $\begin{array}{l}\text { Reklamlarda duyguları } \\
\text { mesajlar/görüntüler (aşk, mutluluk, heyecan, eğlence } \\
\text { gibi) kullanılmaktadır. }\end{array}$ & 4,16 & ,954 & & \\
\hline & $\begin{array}{l}\text { Otelimiz müsşterilerin huzurlu olabileceği bir ortam } \\
\text { sağlamaya çalışır. }\end{array}$ & 4,28 & ,924 & & \\
\hline \multirow{4}{*}{ 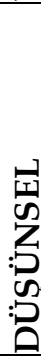 } & $\begin{array}{l}\text { Otelimizde müssteriler için spor kurslarının olmasına } \\
\text { özen gösterilmektedir. }\end{array}$ & 3,47 & 1,270 & \multirow{4}{*}{3,7500} & \multirow{4}{*}{91140} \\
\hline & $\begin{array}{l}\text { Otel aktivitelerinin oluşturulmasında müş̧eriyi eğitici } \\
\text { olmasına özen gösterilmektedir }\end{array}$ & 3,81 & 1,091 & & \\
\hline & $\begin{array}{l}\text { Müşteriler web sayfamızdan ve personelimizden } \\
\text { otelin bulunduğu yöre hakkında bilgi edinebilir. }\end{array}$ & 4,22 & ,792 & & \\
\hline & $\begin{array}{l}\text { Otelimizde müşteriler için hobi kurslarının olmasına } \\
\text { dikkat edilir. }\end{array}$ & 3,50 & 1,218 & & \\
\hline \multirow{4}{*}{ 离 } & $\begin{array}{l}\text { Otelimizde müşteriler için SPA aktivitelerinin } \\
\text { bulunmasına özen gösterilir. }\end{array}$ & 4,22 & 941 & \multirow{4}{*}{3,8984} & \multirow{4}{*}{,82026 } \\
\hline & $\begin{array}{l}\text { Müşterilerimiz otelde çeşitli yaşam stillerini } \\
\text { deneyimleyebilir. }\end{array}$ & 3,69 & 1,061 & & \\
\hline & Müşterilerimiz birey olarak kendini geliştirebilir. & 3,66 & 1,208 & & \\
\hline & $\begin{array}{l}\text { Otelimizde tatil yapan müşteriler kendilerinde } \\
\text { değişim yaşar. }\end{array}$ & 4,03 & 822 & & \\
\hline \multirow{3}{*}{ 包 } & $\begin{array}{l}\text { Web sayfamız müşterilerimize interaktif iletişim } \\
\text { ortamı sağlamaktadır. }\end{array}$ & 4,09 & 928 & \multirow{3}{*}{3,8854} & \multirow{3}{*}{ 90641, } \\
\hline & $\begin{array}{l}\text { Otelimizde müşteriler için kişiselleştirilmiş hizmetler } \\
\text { verilmektedir. }\end{array}$ & 3,81 & 1,176 & & \\
\hline & $\begin{array}{l}\text { Otelimizde müşterilerin sosyalleşmesini sağlayıcı } \\
\text { aktiviteler bulunmaktadır. }\end{array}$ & 3,75 & 1,218 & & \\
\hline
\end{tabular}


5.4. Yöneticilerin Çalıştıkları Otel İşletmelerinin Yıldız Sayısına Göre Deneyim boyutları ve Deneyim Modüllerine Bakış Açıları Arasındaki Farklılık

\section{Durumu}

Katılımcı sayısının az olması sebebiyle bu ve bundan sonraki analizlerde nonparametrik testler kullanılmıştır. Katılımcıların çalıştıkları otel işletmelerinin yıldız sayılarının deneyim boyutlarına ve deneyim modüllerine bakış açıları arasında fark yaratıp yaratmadığını belirlemek için kurulan hipotez şöyledir;

H1: Katılımcıların çalıştıkları otel işletmelerinin yıldız sayılarına göre deneyim boyutlarına ve deneyim modüllerine bakış açıları arasında fark vardır.

Tablo 4. Katılımcıların Çalıştıkları Otel İşletmelerinin Yıldız Sayılarına Göre

Deneyim Boyutları ve Deneyim Modüllerine Bakış Açıları Arasında Farklılık

\section{Durumu}

\begin{tabular}{|c|c|c|c|c|c|c|}
\hline & \multirow{2}{*}{$\begin{array}{l}\text { Otel Yildız } \\
\text { Sayısı }\end{array}$} & \multirow{2}{*}{$\mathrm{N}$} & \multirow{2}{*}{ Sira Ortalaması } & \multirow{2}{*}{ Sira Toplamı } & \multicolumn{2}{|c|}{ Mann-Whitney U } \\
\hline & & & & & Z & $\mathrm{P}$ \\
\hline \multirow{2}{*}{ Ĕgitim } & 4 & 22 & 17,02 & 374,50 & \multirow{2}{*}{,- 472} & \multirow{2}{*}{ 637 } \\
\hline & 5 & 10 & 15,35 & 153,50 & & \\
\hline \multirow{2}{*}{ Estetik } & 4 & 22 & 16,86 & 371,00 & \multirow{2}{*}{,- 328} & \multirow{2}{*}{ 743 } \\
\hline & 5 & 10 & 15,70 & 157,00 & & \\
\hline \multirow{2}{*}{ Kaçış } & 4 & 22 & 16,70 & 367,50 & \multirow{2}{*}{,- 184} & \multirow{2}{*}{,854 } \\
\hline & 5 & 10 & 16,05 & 160,50 & & \\
\hline \multirow{2}{*}{ Eğlence } & 4 & 22 & 17,20 & 378,50 & \multirow{2}{*}{,- 638} & \multirow{2}{*}{, 523} \\
\hline & 5 & 10 & 14,95 & 149,50 & & \\
\hline \multirow{2}{*}{ Duyusal } & 4 & 22 & 18,18 & 400,00 & \multirow{2}{*}{$-1,533$} & \multirow{2}{*}{,125 } \\
\hline & 5 & 10 & 12,80 & 128,00 & & \\
\hline \multirow{2}{*}{ Duygusal } & 4 & 22 & 16,89 & 371,50 & \multirow{2}{*}{,- 354} & \multirow{2}{*}{,723 } \\
\hline & 5 & 10 & 15,65 & 156,50 & & \\
\hline \multirow{2}{*}{ Düşünsel } & 4 & 22 & 17,70 & 389,50 & \multirow{2}{*}{$-1,089$} & \multirow{2}{*}{,276 } \\
\hline & 5 & 10 & 13,85 & 138,50 & & \\
\hline \multirow{2}{*}{ Davranışsal } & 4 & 22 & 17,66 & 388,50 & \multirow{2}{*}{$-1,048$} & \multirow{2}{*}{ 295 } \\
\hline & 5 & 10 & 13,95 & 139,50 & & \\
\hline \multirow{2}{*}{ İlişkisel } & 4 & 22 & 17,84 & 392,50 & \multirow{2}{*}{$-1,223$} & \multirow{2}{*}{,221 } \\
\hline & 5 & 10 & 13,55 & 135,50 & & \\
\hline
\end{tabular}

Katılımcıların çalıştıkları otel işletmelerinin yıldız sayılarına göre deneyim boyutlarına ve deneyim modüllerine bakış açıları arasında farklılık olup olmadığını belirlemek üzere yapılan Mann-Whitney U testi sonuçları Tablo 4'de verilmiştir.

4 yıldızlı otel işletmesinde ya da 5 yıldızlı otel işletmesinde çalışan katılımcıların deneyim boyutlarına ve deneyim modüllerine bakış açıları arasında anlamlı bir 
farklılık olmadığı görülmektedir $(\mathbf{p}>0,05)$. Buna göre, Katılımcıların çalıştıkları otel işletmelerinin yıldız sayılarına göre deneyim boyutlarına ve deneyim modüllerine bakış açıları arasında fark vardır hipotezi desteklenmemiştir.

\subsection{Yöneticilerin Çalıştıkları Otel İşletmelerinin Faaliyet Durumuna Göre} Deneyim boyutları ve Deneyim Modüllerine Bakış Açıları Arasındaki Farklılık

\section{Durumu}

Katılımcıların çalıştıkları otel işletmelerinin faaliyet durumlarına göre deneyim boyutlarına ve deneyim modüllerine bakış açıları arasında fark yaratıp yaratmadığını belirlemek için kurulan hipotez şöyledir;

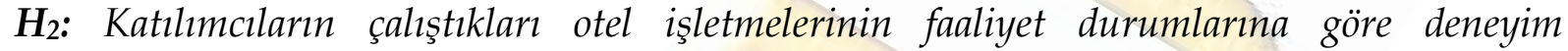
boyutlarına ve deneyim modüllerine bakış açıları arasında fark vardır.

Katılımcıların çalıştıkları otel işletmelerinin faaliyet durumlarına göre deneyim boyutlarına ve deneyim modüllerine bakış açıları arasında farklılık olup olmadığını belirlemek üzere yapılan Mann-Whitney U testi sonuçları Tablo 5’ de verilmiştir.

Tablo 5. Katılımcıların Çalıştıkları Otel İşletmelerinin Faaliyet Durumlarına Göre

Deneyim Boyutları ve Deneyim Modüllerine Bakış Açıları Arasında Farklılık

\section{Durumu}

\begin{tabular}{|c|c|c|c|c|c|c|}
\hline & Otel Faaliyet & $\mathrm{N}$ & Sura Ortalamasi & Sura Tonlam & \multicolumn{2}{|c|}{ Mann-Whitney U } \\
\hline & Durumu & & & & $\mathrm{Z}$ & $\mathrm{P}$ \\
\hline \multirow{2}{*}{ Eğitim } & Devamlı & 7 & 20,14 & 141,00 & \multirow{2}{*}{$-1,174$} & \multirow{2}{*}{240} \\
\hline & Mevsimlik & 25 & 15,48 & 387,00 & & \\
\hline \multirow{2}{*}{ Estetik } & Devamlı & 7 & 19,36 & 135,50 & \multirow{2}{*}{,- 920} & \multirow{2}{*}{,358 } \\
\hline & Mevsimlik & 25 & 15,70 & 392,50 & & \\
\hline \multirow{2}{*}{ Kaçış } & Devamlı & 7 & 17,57 & 123,00 & \multirow{2}{*}{,- 345} & \multirow{2}{*}{,730 } \\
\hline & Mevsimlik & 25 & 16,20 & 405,00 & & \\
\hline \multirow{2}{*}{ Ĕ̆lence } & Devamlı & 7 & 17,07 & 119,50 & \multirow{2}{*}{,- 185} & \multirow{2}{*}{854} \\
\hline & Mevsimlik & 25 & 16,34 & 408,50 & & \\
\hline \multirow{2}{*}{ Duyusal } & Devamlı & 7 & 19,21 & 134,50 & \multirow{2}{*}{,- 883} & \multirow{2}{*}{,378 } \\
\hline & Mevsimlik & 25 & 15,74 & 393,50 & & \\
\hline \multirow{2}{*}{ Duygusal } & Devamlı & 7 & 18,93 & 132,50 & \multirow{2}{*}{,- 794} & \multirow{2}{*}{,427 } \\
\hline & Mevsimlik & 25 & 15,82 & 395,50 & & \\
\hline \multirow{2}{*}{ Düşünsel } & Devamlı & 7 & 17,79 & 124,50 & \multirow{2}{*}{,- 415} & \multirow{2}{*}{678} \\
\hline & Mevsimlik & 25 & 16,14 & 403,50 & & \\
\hline \multirow{2}{*}{ Davranışsal } & Devamlı & 7 & 19,21 & 134,50 & \multirow{2}{*}{,- 875} & \multirow{2}{*}{,382 } \\
\hline & Mevsimlik & 25 & 15,74 & 392,50 & & \\
\hline \multirow{2}{*}{ İlişkisel } & Devamlı & 7 & 16,43 & 115,00 & \multirow{2}{*}{,- 023} & \multirow{2}{*}{ 981 } \\
\hline & Mevsimlik & 25 & 16,52 & 413,00 & & \\
\hline
\end{tabular}


Mevsimlik otel işletmesinde ya da devamlı otel işletmesinde çalışan katılımcıların deneyim boyutlarına ve deneyim modüllerine bakış açıları arasında anlamlı bir farklılık olmadığı görülmektedir $(p>0,05)$. Buna göre, Katılımcıların çalıştıkları otel işletmelerinin faaliyet durumlarına göre deneyim boyutlarına ve deneyim modüllerine bakış açıları arasında fark vardır hipotezi desteklenmemiştir.

\subsection{Katılımcıların Otellerinin Faaliyet Sürelerine Göre Deneyim Boyutlarına} ve Deneyim Modüllerine Bakış Açıları Arasındaki Farklılık Durumu

Katılımcıların otellerinin faaliyet süreleri deneyim boyutlarına ve deneyim modüllerine bakış açıları arasında fark yaratıp yaratmadığını belirlemek için kurulan hipotez şöyledir;

H3: Katılimcilarm otellerinin faaliyet sürelerine göre deneyim boyutlarna ve deneyim modüllerine bakış açıları arasında fark vardır.

Katılımcıların otellerinin faaliyet sürelerine göre deneyim boyutlarına ve deneyim modüllerine bakış açıları arasında farklılık olup olmadığını belirlemek üzere yapılan Kruskal Wallis testi sonuçları Tablo 6' da verilmiştir.

Farklı otel faaliyet süresine sahip katılımcıların deneyim boyutlarından estetik, kaçış ve eğlence, deneyim modüllerinden duyusal ve duygusala bakış açıları arasında anlamlı bir farklılık olmadığı görülmüştür $(p>0,05)$. Bu boyut ve modüllerde, Katılımcıların otellerinin faaliyet sürelerine göre deneyim boyutlarına ve deneyim modüllerine bakış açıları arasında fark vardır hipotezi desteklenmemiştir. Buna karşın farklı otel faaliyet süresine sahip katılımcıların deneyim boyutlarından eğitim, deneyim modüllerinden düşünsel, davranışsal ve ilişkisele bakış açıları arasında anlamlı bir farklılık olduğu görülmüştür $(\mathrm{p}<0,05)$. Bu boyut ve modüllerde, Katılımcıların otellerinin faaliyet sürelerine göre deneyim boyutlarına ve deneyim modüllerine bakış açıları arasında fark vardır $\left(\mathrm{H}_{3}\right)$ hipotezi desteklenmiştir. Bu boyut ve modüllerde farklılığın hangi gruplar arasından kaynaklandığını tespit etmek üzere gruplar arasında ikili olarak Mann-Whitney U testi gerçekleştirilmiştir. 
Tablo 6. Katılımcıların Otellerinin Faaliyet Sürelerine Göre Deneyim Boyutlarına ve Deneyim Modüllerine Bakış Açıları Arasında Farklılık Durumu

\begin{tabular}{|c|c|c|c|c|c|c|}
\hline & Otel faaliyet Süreleri & $\mathrm{N}$ & Sira Ortalaması & $\mathrm{X} 2$ & sd & $\mathrm{p}$ \\
\hline \multirow{4}{*}{ Ĕgitim } & 10 Yildan Az & 8 & 20,38 & \multirow{4}{*}{8,137} & \multirow{4}{*}{3} & \multirow{4}{*}{,043 } \\
\hline & $11-15$ & 9 & 12,67 & & & \\
\hline & $16-20$ & 5 & 9,00 & & & \\
\hline & 21 Yil ve Üstü & 10 & 20,60 & & & \\
\hline \multirow{4}{*}{ Estetik } & 10 Yildan Az & 8 & 17,75 & \multirow{4}{*}{ 750 } & \multirow{4}{*}{3} & \multirow{4}{*}{861} \\
\hline & 11-15 & 9 & 14,33 & & & \\
\hline & $16-20$ & 5 & 16,40 & & & \\
\hline & 21 Yil ve Üstü & 10 & 17,50 & & & \\
\hline \multirow{4}{*}{ Kaçış } & 10 Yildan Az & 8 & 18,69 & \multirow{4}{*}{6,112} & \multirow{4}{*}{3} & \multirow{4}{*}{ 106 } \\
\hline & $11-15$ & 9 & 11,94 & & & \\
\hline & $16-20$ & 5 & 12,10 & & & \\
\hline & 21 Yil ve Üstü & 10 & 21,05 & & & \\
\hline \multirow{4}{*}{ Eğlence } & 10 Yildan Az & 8 & 18,63 & \multirow{4}{*}{7,075} & \multirow{4}{*}{3} & \multirow{4}{*}{,070 } \\
\hline & $11-15$ & 9 & 12,39 & & & \\
\hline & $16-20$ & 5 & 10,60 & & & \\
\hline & 21 Yll ve Üstü & 10 & 21,45 & & & \\
\hline \multirow{4}{*}{ Duyusal } & 10 Yildan Az & 8 & 18,69 & \multirow{4}{*}{2,650} & \multirow{4}{*}{3} & \multirow{4}{*}{,449 } \\
\hline & $11-15$ & 9 & 13,61 & & & \\
\hline & $16-20$ & 5 & 13,30 & & & \\
\hline & 21 Yil ve Üstü & 10 & 18,95 & & & \\
\hline \multirow{4}{*}{ Duygusal } & 10 Yildan Az & 8 & 14,19 & \multirow{4}{*}{2,146} & \multirow{4}{*}{3} & \multirow{4}{*}{, 543} \\
\hline & $11-15$ & 9 & 14,83 & & & \\
\hline & $16-20$ & 5 & 16,50 & & & \\
\hline & 21 Yil ve Üstü & 10 & 19,85 & & & \\
\hline \multirow{4}{*}{ Düşüunsel } & 10 Yildan Az & 8 & 17,06 & \multirow{4}{*}{8,633} & \multirow{4}{*}{3} & \\
\hline & $11-15$ & 9 & 12,17 & & & 025 \\
\hline & $16-20$ & 5 & 10,70 & & & ,030 \\
\hline & 21 Yıl ve Üstü & 10 & 22,85 & & & \\
\hline & 10 Yildan Az & 8 & 18,13 & & & \\
\hline Davranışsal & $11-15$ & 9 & 10,89 & 8644 & 3 & 034 \\
\hline & $16-20$ & 5 & 12,20 & 0,044 & o &, 034 \\
\hline & 21 Yil ve Üstü & 10 & 22,40 & & & \\
\hline & 10 Yildan Az & 8 & 14,88 & & & \\
\hline İlisskisel & $11-15$ & 9 & 12,33 & 80 & ? & $0>0$ \\
\hline & $16-20$ & 5 & 12,90 & 8,406 & 3 & ,038 \\
\hline & 21 Yil ve Üstü & 10 & 23,35 & & & \\
\hline
\end{tabular}


Tablo 7. Katılımcıların Otellerinin Faaliyet Sürelerine Göre Deneyim Boyutlarına ve Deneyim Modüllerine Bakış Açıları Arasında Farklılıklara Ait Mann-Whitney U Testi Sonuçları

\begin{tabular}{|c|c|c|c|c|c|c|}
\hline & Otel Faaliyet & & & & Mann- & ney U \\
\hline & Süresi & $\mathrm{N}$ & Sira Ortalamas1 & Sira Toplam1 & $\mathrm{Z}$ & $\mathrm{P}$ \\
\hline & 10 yıldan az & 8 & 11,50 & 92,00 & & 050 \\
\hline & $11-15$ & 9 & 6,78 & 61,00 & $-1,956$ & - \\
\hline & 10 yıldan az & 8 & 9,00 & 72,00 & & \\
\hline & $16-20$ & 5 & 3,80 & 19,00 & $-2,389$ & - \\
\hline & 10 yıldan az & 8 & 8,88 & 71,00 & & \\
\hline Ĕ̈.tim & 21 ve üzeri & 10 & 10,00 & 100,00 & - & 647 \\
\hline Egitim & $11-15$ & 9 & 8,17 & 73,50 & & \\
\hline & $16-20$ & 5 & 6,30 & 31,50 &,- 819 & 413 \\
\hline & $11-15$ & 9 & 7,72 & 69,50 & & \\
\hline & 21 ve üzeri & 10 & 12,05 & 120,50 & $-1,692$ & 091 \\
\hline & $16-20$ & 5 & 4,90 & 24,50 & & \\
\hline & 21 ve üzeri & 10 & 9,55 & 95,50 & $-1,926$ & ,054 \\
\hline & 10 yildan az & 8 & 10,63 & 85,00 & & \\
\hline & $11-15$ & 9 & 7,56 & 68,00 & $-1,26 \%$ & 205 \\
\hline & 10 yildan az & 8 & 8,00 & 64,00 & & \\
\hline & $16-20$ & 5 & 5,40 & 27,00 & $-1,206$ & 228 \\
\hline & 10 yildan az & 8 & 7,44 & 59,50 & 1505 & 122 \\
\hline Dii & 21 ve üzeri & 10 & 11,15 & 111,50 & $-1,500$ & , 132 \\
\hline Duşunsel & $11-15$ & 9 & 7,94 & 71,50 & 541 & 500 \\
\hline & $16-20$ & 5 & 6,70 & 33,50 & - & - \\
\hline & $11-15$ & 9 & 6,67 & 60,00 & 2471 & \\
\hline & 21 ve üzeri & 10 & 13,00 & 130,00 & $-2,471$ & - 013, \\
\hline & $16-20$ & 5 & 4,60 & 23,00 & 2112 & 020 \\
\hline & 21 ve üzeri & 10 & 9,70 & 97,00 & $-2,142$ & , \\
\hline & 10 yildan az & 8 & 11,25 & 90,00 & 1750 & 080 \\
\hline & $11-15$ & 9 & 7,00 & 63,00 & $-1,150$ & - \\
\hline & 10 yildan az & 8 & 8,00 & 64,00 & & \\
\hline & $16-20$ & 5 & 5,40 & 27,00 & $-1,193$ & 233 \\
\hline & 10 yildan az & 8 & 7,88 & 63,00 & 1102 & 227 \\
\hline Daum & 21 ve üzeri & 10 & 10,80 & 108,00 & $-1,182$ & , 237 \\
\hline Davranişsal & $11-15$ & 9 & 7,33 & 66,00 & 200 & 090 \\
\hline & $16-20$ & 5 & 7,80 & 39,00 &,$- \angle U L$ & , 840 \\
\hline & $11-15$ & 9 & 6,56 & 59,00 & 2555 & 011 \\
\hline & 21 ve üzeri & 10 & 13,10 & 131,00 & $-2,350$ & - \\
\hline & $16-20$ & 5 & 5,00 & 25,00 & 1867 & 062 \\
\hline & 21 ve üzeri & 10 & 9,50 & 95,00 & $-1,86 /$ &, 062 \\
\hline & 10 yildan az & 8 & 9,88 & 79,00 & 700 & 170 \\
\hline & $11-15$ & 9 & 8,22 & 74,00 & - & , $4 / 9$ \\
\hline & 10 yıldan az & 8 & 7,19 & 57,50 & 227 & 801 \\
\hline & $16-20$ & 5 & 6,70 & 33,50 &,$- 2 \angle 7$ & , 821 \\
\hline & 10 yildan az & 8 & 6,81 & 54,50 & 1004 & \\
\hline iliskical & 21 ve üzeri & 10 & 11,65 & 116,50 & $-1,984$ & - \\
\hline Mişkisel & $11-15$ & 9 & 7,61 & 68,50 & 142 & 006 \\
\hline & $16-20$ & 5 & 7,30 & 36,50 &,- 143 & (8) \\
\hline & $11-15$ & 9 & 6,50 & 58,50 & & \\
\hline & 21 ve üzeri & 10 & 13,15 & 131,50 & $-2,642$ & (008 \\
\hline & $16-20$ & 5 & 4,90 & 24,50 & 1042 & $0=?$ \\
\hline & 21 ve üzeri & 10 & 9,55 & 95,50 & $-1,942$ & , \\
\hline
\end{tabular}


Tablo 7 incelendiğinde eğitim boyutundaki farklılığın 10 yıldan az faaliyet süresine sahip otel işletmelerinde çalışan yöneticilerin 11-15 ve 16-20 yıl arası faaliyette bulunan otellerde çalışan yöneticilerin vermiş oldukları cevaplardan kaynaklandığ1 görülmektedir. Sıra ortalamaları incelendiğinde 10 yıldan az faaliyet süresine sahip otel işletmelerinde eğitim boyutuna daha fazla önem verildiği görülmektedir.

\subsection{Katılımcıların Otellerinin Kapasitelerine Göre Deneyim Boyutlarına ve} Deneyim Modüllerine Bakış Açıları Arasındaki Farklılık Durumu

Katılımcıların otellerinin kapasiteleri deneyim boyutlarına ve deneyim modüllerine bakış açıları arasında fark yaratıp yaratmadığını belirlemek için kurulan hipotez şöyledir;

$\mathrm{H}_{4}$ : Katılımcıların otellerinin kapasitelerine göre deneyim boyutlarına ve deneyim modüllerine bakış açıları arasında fark vardır.

Katılımcıların otellerinin kapasitelerine göre deneyim boyutlarına ve deneyim modüllerine bakış açıları arasında farklılık olup olmadığını belirlemek üzere yapılan Kruskal Wallis testi sonuçları Tablo 8'de verilmiştir.

Farklı otel kapasitesine sahip katılımcıların deneyim boyutlarının tümünde, deneyim modüllerinden duyusal, davranışsal, düşünsel ve ilişkisele bakış açıları arasında anlamlı bir farklılık olmadığ1 görülmüştür ( $\mathbf{p}>0,05)$. Bu boyut ve modüllerde, Katılımcıların otellerinin kapasitelerine göre deneyim boyutlarına ve deneyim modüllerine bakış açıları arasında fark vardır hipotezi desteklenmemiştir. Buna karşın farklı otel kapasitelerine sahip katılımcıların deneyim modüllerinden duygusal modüle bakış açıları arasında anlamlı bir farklılık olduğu görülmüştür $(\mathbf{p}<0,05)$. Bu modülde, Katılımcıların otellerinin kapasitelerine göre deneyim modüllerine bakış açıları arasında fark vardır $\left(\mathrm{H}_{4}\right)$ hipotezi desteklenmiştir. Bu modülde farklılığın hangi gruplar arasından kaynaklandığını tespit etmek üzere gruplar arasında ikili olarak Mann-Whitney U testi gerçekleştirilmiştir. 
Tablo 8. Katılımcıların Otellerinin Kapasitelerine Göre Deneyim Boyutlarına ve Deneyim Modüllerine Bakış Açıları Arasında Farklılık Durumu

\begin{tabular}{|c|c|c|c|c|c|c|}
\hline \multirow{4}{*}{ Eğitim } & Otel Kapasiteleri & $\mathrm{N}$ & Sira Ortalaması & $\mathrm{X} 2$ & $\mathrm{sd}$ & $\mathrm{p}$ \\
\hline & 150 Odanın Altında & 14 & 16,43 & \multirow{3}{*}{ 717 } & \multirow{3}{*}{2} & \multirow{3}{*}{ 699 } \\
\hline & $150-299$ & 10 & 14,90 & & & \\
\hline & 300 ve Üzeri & 8 & 18,63 & & & \\
\hline \multirow{3}{*}{ Estetik } & 150 Odanın Altında & 14 & 18,75 & \multirow{3}{*}{2,836} & \multirow{3}{*}{2} & \multirow{3}{*}{ 242 } \\
\hline & $150-299$ & 10 & 12,45 & & & \\
\hline & 300 ve Üzeri & 8 & 17,63 & & & \\
\hline \multirow{3}{*}{ Kaçış } & 150 Odanın Altında & 14 & 17,29 & \multirow{3}{*}{3,343} & \multirow{3}{*}{2} & \multirow{3}{*}{ 188 } \\
\hline & $150-299$ & 10 & 12,40 & & & \\
\hline & 300 ve Üzeri & 8 & 20,25 & & & \\
\hline \multirow{3}{*}{ Eğlence } & 150 Odanın Altında & 14 & 18,64 & \multirow{3}{*}{3,823} & \multirow{3}{*}{2} & \multirow{3}{*}{ 148 } \\
\hline & $150-299$ & 10 & 11,75 & & & \\
\hline & 300 ve Üzeri & 8 & 18,69 & & & \\
\hline \multirow{3}{*}{ Duyusal } & 150 Odanın Altında & 14 & 19,14 & \multirow{3}{*}{2,462} & \multirow{3}{*}{2} & \multirow{3}{*}{ 292 } \\
\hline & $150-299$ & 10 & 13,20 & & & \\
\hline & 300 ve Üzeri & 8 & 16,00 & & & \\
\hline \multirow{3}{*}{ Duygusal } & 150 Odanın Altında & 14 & 18,00 & \multirow{3}{*}{8,013} & \multirow{3}{*}{2} & \multirow{3}{*}{018} \\
\hline & $150-299$ & 10 & 10,10 & & & \\
\hline & 300 ve Üzeri & 8 & 21,88 & & & \\
\hline \multirow{3}{*}{ Düşünsel } & 150 Odanın Altında & 14 & 18,43 & \multirow{3}{*}{2,341} & \multirow{3}{*}{2} & \multirow{3}{*}{,310 } \\
\hline & $150-299$ & 10 & 12,80 & & & \\
\hline & 300 ve Üzeri & 8 & 17,75 & & & \\
\hline \multirow{3}{*}{ Davranışsal } & 150 Odanın Altında & 14 & 18,07 & \multirow{3}{*}{1,405} & \multirow{3}{*}{2} & \multirow{3}{*}{ 495 } \\
\hline & $150-299$ & 10 & 13,65 & & & \\
\hline & 300 ve Üzeri & 8 & 17,31 & & & \\
\hline & 150 Odanın Altında & 14 & 18,75 & & & \\
\hline Ilişkisel & $150-299$ & 10 & 10,80 & 5,637 & 2 & , 060 \\
\hline & 300 ve Üzeri & 8 & 19,69 & & & \\
\hline
\end{tabular}

Tablo 9. Katılımcıların Otellerinin Kapasitesine Göre Duygusal Deneyim Modülüne Bakış Açıları Arasındaki Farklılıklara Ait Mann-Whitney U Testi Sonuçları

\begin{tabular}{|c|c|c|c|c|c|c|}
\hline & \multirow{2}{*}{$\begin{array}{c}\text { Otel } \\
\text { Kapasitesi }\end{array}$} & \multirow{2}{*}{$\mathrm{N}$} & \multirow{2}{*}{ Sira Ortalaması } & \multirow{2}{*}{ Sıra Toplamı } & \multicolumn{2}{|c|}{ Mann-Whitney U } \\
\hline & & & & & Z & $\mathrm{P}$ \\
\hline \multirow{6}{*}{ Duygusal } & $\begin{array}{l}150 \text { odanın } \\
\text { altında }\end{array}$ & 14 & 14,93 & 209,00 & \multirow{2}{*}{$-2,045$} & \multirow[t]{2}{*}{,041 } \\
\hline & $150-299$ & 10 & 9,10 & 91,00 & & \\
\hline & $\begin{array}{l}150 \text { odanın } \\
\text { altında }\end{array}$ & 14 & 10,57 & 148,00 & \multirow{2}{*}{,- 923} & \multirow{2}{*}{,356 } \\
\hline & 300 ve üzeri & 8 & 13,13 & 105,00 & & \\
\hline & $150-299$ & 10 & 6,50 & 65,00 & \multirow{2}{*}{$-2,698$} & \multirow{2}{*}{,007 } \\
\hline & 300 ve üzeri & 8 & 13,25 & 106,00 & & \\
\hline
\end{tabular}


Tablo 9 incelendiğinde duygusal modüldeki farklılığın 150 odanın altında kapasiteye sahip oteller ile 150-299 oda kapasitesine sahip oteller arasindan ve 150-299 odaya sahip oteller ile 300 ve üzeri odaya sahip otellerden kaynaklandiğ 1 görülmektedir. Sıra ortalamaları incelendiğinde 150-299 odaya sahip otellerin duygusal deneyim modülüne daha fazla önem verdikleri görülmektedir.

\section{SONUÇ VE ÖNERİLER}

Günümüz küresel rekabet koşulları içerisinde işletmeler müşterilerine yönelik olarak gerçekleştirdikleri farklı pazarlama taktikleri ile kendi müşterilerini arttırma çabaları içerisindedirler. Müşteriler ise satın alacakları ürünün kendilerine sağlayacağı faydanın yanında ne tür kazanımlar elde edeceklerinin hesabını yapmaktadırlar. Müşteriler satın alacakları ürün ya da hizmetten en üst düzeyde fayda beklemektedir. Bunun dışında müşteriler için önemli konulardan bir tanesi de deneyim konusudur. Müşteriler için satın aldıkları ürün ya da hizmetten elde edecekleri farklı olumlu deneyimler onların satın alma davranışlarını etkilemektedir. Bu nedenle işletmeler müşterilerine farklı deneyimler yaşatarak satışlarını dolayısıyla karlılıklarını arttırma düşüncesinde birleşmektedirler.

Turizm işletmeleri içerisinde yer alan otel işletmeleri için de misafirlerine yaşatacakları deneyimler önem taşımaktadır. Otel işletmesine gelen misafirler yaşadıkları unutulmaz olumlu deneyimler sonucunda belki de tatilleri bitmeden otelin tanıtımını yapabilmektedirler. Yaşadıkları deneyimleri sosyal medya aracılı̆̆ı ile paylaşan misafirler anında otel tanıtımını gerçekleştirebilmektedirler. Otel işletmelerinin birbirine benzeyen birçok hizmeti bulunmaktadır. Otel işletmeleri farklılaşabilmek adına misafirlerine yaşattıkları deneyimler ile birlikte deneyimsel pazarlamayı kullanabilmektedirler. Deneyimsel pazarlama uygulamaları ile birlikte otel işletmeleri misafirlerinin memnuniyetini ve sadakatlerini sağlayabilmektedirler. Memnuniyet düzeyleri yüksek olan ve sadakatleri sağlanan misafirler tekrar aynı otel işletmesini tercih edebilmektedirler. Aynı zamanda yaptıkları tanıtımlar ile otel işletmelerine yeni müşteriler sağlayabilmektedirler. Bu nedenle otel işletmeleri farklı deneyim modüllerine ve boyutlarına önem vermektedirler. Bu doğrultuda otel yöneticileri bakış açısıyla deneyimsel pazarlama modüllerinin ve boyutlarının 
incelenmesi temel amacı ile gerçekleştirilen bu çalışmada farklı sonuçlar elde edilmiştir.

Yapılan çalışma Kuşadası'nda faaliyette bulunan 4 ve 5 yıldızlı otel işletmelerinden yöneticiler ile gerçekleştirilmiştir. Çalışmaya katılanların büyük bölümü 4 yıldızlı otel işletmesinde çalışmaktadır. Otel işletmelerinin büyük bir bölümü mevsimlik olarak sezonda faaliyette bulunmaktadır. Otel işletmelerinin büyük bir bölümü 21 yıl ve üzerinde faaliyette bulunurken yine büyük bir bölümü 150 oda ve altında bir kapasiteye sahiptir.

Yapılan çalışmada elde edilen bulgulara göre ortalamalar açısında deneyim boyutlarından en düşük ortalamaya eğitim boyutu sahiptir. Eğitim boyutu içerisinde ise "Çoğu misafirimiz yeni bir şeyler öğrenebildiği için otelimize tekrar gelmektedir." İfadesi en düşük ortalamaya sahiptir. Katılımcıların vermiş oldukları cevaplara göre en yüksek ortalamaya estetik boyutu sahipken estetik boyutu içerisinde ise “Restoranlarımızda sunulan yemeklerin görüntüsü ve lezzetine dikkat edilmektedir." İfadesi en yüksek ortalamaya sahiptir. Boyutların genel ortalamaları dikkate alındığında Çoşkunoğlu (2019) tarafından benzer olarak yapılan çalışmada en düşük ortalamaya estetik boyutu sahipken en yüksek ortalamaya eğitim boyutu sahiptir. Yine benzer şekilde Çeltek (2010) tarafından yapılan çalışmada en düşük ortalamaya eğitim boyutu sahipken en yüksek ortalamaya kaçış boyutu sahiptir. Bu açıdan çalışma Çoşkunoğlu (2019) tarafından yapılan çalışmanın bulguları ile tam tersi olarak ortaya çıkmaktadır. Çeltek tarafından yapılan çalışma ile ise en düşük ortalamaya sahip olan eğitim boyutu ile örtüşmektedir. Yapılan çalışmada en düşük ortalamaya sahip olarak eğitim boyutunun çıkması otellerin büyük bir bölümünün sezonluk işletmeler olmasından kaynaklanabilir. Ya da bu otel işletmelerinin sezonda daha çok eğlence ve estetiğe önem vermelerinden kaynaklanabilir.

Deneyim modülleri ortalamaları incelendiğinde ise çalışmada en düşük ortalamaya düşünsel modül sahiptir. Düşünsel modül içerisinde ise "Otelimizde müşteriler için spor kurslarının olmasına özen gösterilmektedir." İfadesi en düşük ortalamaya sahiptir. Deneyim modülleri incelendiğinde katılımcıların vermiş oldukları cevaplara göre en yüksek ortalamaya duygusal modül sahiptir. Duygusal 
modül içerisinde ise "Otelimiz müşterilerin huzurlu olabileceği bir ortam sağlamaya çalışır." İfadesi en yüksek ortalamaya sahiptir. Coşkunoğlu (2019) ve Çeltek (2010) tarafından benzer şekilde gerçekleştirilen çalışmaların bulguları ile karşılaştırıldığında Coşkunoğlu (2019) tarafından gerçekleştirilen çalışmada en yüksek ortalamaya davranışsal modül en düşük ortalamaya sahip modül ise duyusal modüldür. Çeltek (2010) tarafından gerçekleştirilen çalışmada ise en yüksek ortalamaya duyusal/duygusal en düşük ortalama ise düşünsel/davranışsal modül sahiptir. Bu açıdan her ne kadar boyutlar birleşmiş olsa da çalışma Çeltek (2010) tarafından gerçekleştirilen çalışma ile benzerlik göstermektedir. Çalışmada özellikle Kuşadası'ndaki otel işletmelerinde müşterilere spor ve hobi kurslarının ortalama açısından az verildiği görülmektedir. Bu durum otel işletmelerinin sezon için daha çok deniz kum güneş tatiline önem vermelerinden kaynaklanıyor olabilir.

Otel işletmelerinde yöneticilerin otellerinin yıldız sayısına ve faaliyet durumlarına göre deneyim boyutlarına ve deneyim modüllerine bakış açılarında bir farklılık bulunmamaktadır. Ancak farklı faaliyet sürelerine sahip otellerde eğitim boyutu ve düşünsel, davranışsal ve ilişkisel modüle bakış açılarında anlamlı bir farklılık bulunmaktadır. Ayrıca farklı otel kapasitelerine sahip katılımcıların deneyim modüllerinden duygusal modüle bakış açıları arasında anlamlı bir farklılık olduğu görülmüştür.

Çalışma bulgularına göre otel yöneticileri özellikle işletmelerinde farklı deneyimler yaşamak için bulunan misafirlerine yeni şeyler öğretmek yolu ile misafirlerinin bu beklentilerine cevap verebilirler. Ayrıca otel işletmeleri misafirlerine farklı spor ve hobi aktiviteleri gibi kursları düzenleyerek misafirlerine bu konularda eğitici olabilirler. Böylece misafirlerinin öğrenme ile ilgili deneyimlerinin karşılanmasına da yardımcı olabilir. Otel işletmeleri için tüm deneyim boyutlarının önemi büyüktür. Yapılan literatür taraması sonucunda otel işletmelerinde deneyim boyutları ve deneyim modülleri müşterilerin satın alma kararlarını tatminlerini ve sadakatlerini etkilemektedir (Kement ve Çavuşoğlu, 2017: 181 Kara ve Çiçek, 2015: 196). Otel işletmeleri deneyim boyutları ve modüllerine önem vererek hem müşterilerinin tatminlerini ve sadakatini arttırabilirler hem de karlılıklarını arttırabilirler. Bu çalışma Kuşadası'nda faaliyette bulunan 4 ve 5 yıldızlı otel 
işletmelerinde çalışan birer yöneticiye yapılan anket çalışması ile gerçekleştirilmiştir. Bu doğrultuda bu çalışma farklı resort otellerde gerçekleştirilebilineceği gibi şehir otellerinde de gerçekleştirilerek karşılaştırmalar yapılabilir. Aynı zamanda çalışma otel işletmelerinde tüm çalışanlara ya da tüm yöneticilere uygulanarak aradaki farklı bakış açları ortaya konabilir. 


\section{KAYNAKÇA}

Akyıldız, M. (2010). Boş Zaman Pazarlamasında Deneyimsel Boyutlar: 2009 Rock'n Coke Festivali Katılımcılarına Yönelik Bir Araştırma, Anadolu Üniversitesi Sağlık Bilimleri Enstitüsü, Beden Eğitimi ve Spor Anabilim Dalı, Yükseklisans Tezi, Eskişehir

Brakus, J. J., Schmitt, B. H. ve Zarantonello, L., (2009). Brand Experience: What Is It? How Is It Measured? Does It Affect Loyalty?, Journal of Marketing, 73-May, 52-68

Coşkunoğlu, H. (2019). Konaklama İşletmelerinde Çallışanların Otel Özelliklerine Göre Deneyimsel Pazarlama Algısı:Trabzon İline Yönelik Bir Araştırma, Avrasya Üniversitesi, Sosyal Bilimler Enstitüsü, Yönetim Bilimleri Anabilim Dalı, Yönetim Bilimleri Bilim Dalı, Yükseklisans Tezi, Trabzon

Çeltek, E. (2010). Deneyimsel Pazarlama Unsurlarının Otellerin Bakış Açısı İle Değerlendirilmesi: Türkiye'deki 4 ve 5 Yıldızlı Otel İşletmelerinde Bir Uygulama, Anadolu Üniversitesi, Sağlık Bilimleri Enstitüsü, Doktora Tezi, Eskişehir.

Deligöz, K. (2014). Deneyimsel Pazarlama Uygulamalarının Marka Tercihi Üzerindeki Etkisini Belirlemeye Yönelik Bir Araştırma (Kahve Dünyası ve Starbucks örneği), Atatürk Üniversitesi Sosyal Bilimler Enstitüsü, Yükseklisasn Tezi, Erzurum.

Garcia, J. A. C., Galindo, A. D. V. ve Suarez, R. M., (2018). The Efect of Online and Offline Experiential Marketing on Brand Equity in the Hotel Sector, Spanish Journal of Marketing, ESIC, 22 (1), 22-41

Oh, H., Fiore, A. M. ve Jeoung, M. (2007). Measuring Experience Economy Concepts: Tourism Applications, Journal of Travel Research, 46; 119-132

Holbrook, M. B. ve Hirschman, E. C. (1982). The Experiential Aspects of Consumption: Consumer Fantasies, Feelings, and Fun, Journal of Consumer Research, 9 (2), 132-140

Ihtiyar, A., Barut, M. ve Ihtiyar, H. G. (2018). Experiential Marketing, Social Judgements, and Customer Shopping Experience in Emerging Markets, Asia Pacific Journal of Marketing and Logistics 31 (2), 499515

Kara, M., ve Çiçek, B. (2015). Deneyimsel Pazarlama ve Satın Alma Karar Sürecine Etkisi: Termal Turizm Sektöründe Bir Uygulama, Gümüshane University Electronic Journal of the Institute of Social Science/Gümüshane Üniversitesi Sosyal Bilimler Enstitüsü Elektronik Dergisi, 6(13), 177-200

Kabadayı, E. T., ve Alan, A. K. (2014). Deneyimsel Pazarlama: Pazarlamadaki Artan Önemi. İşletme Araştırmaları Dergisi. 6/1, 203-217.

Kement, Ü. ve Çavuşoğlu, S. (2017). Hafızaya Yönelik Müşteri Deneyimlerinin Müşteri Sadakatine Etkisi: Yeşil Oteller Örneği, Uluslararası Sosyal ve Eğitim Bilimleri Dergisi, 4(8), 172-194 
Khotimah, K., Sucherly, Sari, D. ve Kaltum, U. (2016). Event Marketing and Experiential Marketing Towards the Formation of Net Marketing Contrubition Margin (NMCM), Procedia-Social and Behavioral Sciences 219, 431-439

Le, D., Scott, N. ve Lohmann, G. (2019). Applying Experiential Marketing in Selling Tourism Dreams, Journal of Travel \& Tourism Marketing, 36(2), 220-235

Lee, T. H. ve Chang, Y. S. (2012). The Influence of Experiential Marketing and Activity Involvement on the Loyalty Intentions of Wine Tourists in Taiwan, Leisure Studies, 31(1), 103-121

Lin, M. TY. (2019). Effects of Experiential Marketing on Experience Value and Customer Satisfaction in Ecotourism, Ekoloji, 28(107), 3151-3156

Lin, K., (2006). An Examination Of The Relationship Between Experiential Marketing Strategy And Guests' Leisure Behavior In Taiwan Hot-Spring Hotels, Thesis For The Degree Of Doctor Of Sport Management United States Sports Academy

Mehmetoğlu, M. ve Engen, M. (2011). Pine and Gilmore's Concept of Experience Economy and Its Dimensions: An Empirical Examination in Tourism, Journal of Quality Assurance in Hospitality \& Tourism, 12(4), 237-255

Oral, S. ve Yetim, A. Ç. (2015). Deneyimsel Değer, Tüketici Tatmini ve Tüketici Sadakati Arasındaki İlişkinin Belirlenmesine Yönelik Bir Araştırma, Dokuz Eylül Üniversitesi Sosyal BilimlerEnstitüsü Dergisi, 16(3), 469-497

Pine, J.B. ve Gilmore, J., (1998). Welcome to Experience Economy, Harvard Business Review, JulyAugust, 97-105

Pine, J. B. ve Gilmore J., (2001). Welcome to the Experience Economy, Health Forum Journal, SeptemberOctober, $4-8$

Pine, J. B. ve Gilmore, J., (2002). Customer Experience Places: The New Offering Frontier, Strategy \& Leadership, 30(4), 4-11

Saltık, I. A., (2011). Turizm Sektöründe Deneyimsel Pazarlama Ve Tüketici Davranışları Üzerine Etkisi, Muğla Üniversitesi Sosyal Bilimler Enstitüsü, Yüksek Lisans Tezi, Muğla

Same, S. ve Larimo, J. (2012). Marketing Theory: Experience Marketing and Experiential Marketing, 7th International Scientific Conference “Business and Management 2012” May 10-11, Vilnius, LITHUANIA, $480-487$

Schmitt, B., (1999). Experiential Marketing, Journal of Marketing Management, 15:1-3, 53-67

Schmitt, B., (2010). Experience Marketing: Concepts, Frameworks and Consumer Insights, Foundations and Trends in Marketing, Vol.5, No.6, 55-112. 
Taşkıran, Ö. ve Kızılırmak, İ. (2019). Deneyimsel Pazarlama Kapsamında Sanal Turların Müze Ziyaretlerine Etkisi: Panorama 1453 Örneği, Uygulamalı Sosyal Bilimler Dergisi, 3(1), 1-19.

Tsaur, S., Chih, Y. ve Wang, C. (2007). The Visitors Behavioral Consequences of Experiential Marketing, Journal of Travel \& Tourism Marketing, 21 (1), 47-64

Tunç, R. (2017). Deneyimsel Pazarlama ve Müşteri Memnuniyeti Üzerine Etkisi, İstanbul Ticaret Üniversitesi Dış Ticaret Enstitüsü, Küresel Pazarlama ve Marka Yönetimi Tezli Yükseklisans Programı, İstanbul

Uygur, S. M. ve Doğan, S. (2013). Deneyimsel Pazarlamanın Müşteri Memnuniyeti Üzerine Etkisi: Restoranlar Üzerine Bir Araştırma, Dumlupınar Üniversitesi Sosyal Bilimler Dergisi, 37, 33-48

Williams, A. (2006). Tourism and Hospitality Marketing:Fantasy, Feeling and Fun, International Journal of Contemporary Hospitality Management, 18 (6), 482-495

Yapraklı, T. Ş. ve Keser, E. (2016). Deneyimsel Pazarlama ve Deneyimsel Değerin Müşteri Memnuniyeti ve Müşteri Sadakati Üzerindeki Etkisi: Nostaljik ve Fast Foof Restoranlar Üzerinde Bir Uygulama, The Journal of Academic Social Science Studies, International Journal of Social Science, 47, 19-35

Yeh, T.-M., Chen, S-H., ve Chen, T-F. (2019). The Relationships among Experiential Marketing, Service Innovation, and Customer Satisfaction-A Case Study of Tourism Factories in Taiwan, Sustainability, $11(4), 10-41$

Yeşilot, F. ve Dal, N. E., (2019). Müşteri Deneyimi Oluşturma ve Deneyimsel Pazarlama: Iyaşpark Alışveriş Merkezi (AVM) Müşterileri ile Bir Araştırma, Mehmet Akif Ersoy Üniversitesi Uygulamalı Bilimler Dergisi, 3(2), 263-296

Yetiş, Ş. A. (2015). Termal Otel İşletmelerinde Deneyimsel Pazarlama Yaklaşımı, KMÜ Sosyal ve Ekonomik Araştırmalar Dergisi, 17 (29), 90-98

Yılmaz, M. K. ve Vahidli, A. (2020). Deneyimsel Pazarlamanın Tüketicilerin Deneyimsel Memnuniyeti ve Tavsiye Etme Niyetine Etkisi: Samsun Golf Kulübü Örneği, Türk Turizm Araştırmaları Dergisi, 4(2): 1454-1476.

Yuan, Y. H. ve Wu, C. K. (2008). Relationships Among Experiential Marketing, Experiential Value, and Customer Satisfaction, Journal of Hospitality \& Tourism Research, 32(3), 387-410

https:/ / aydin.ktb.gov.tr/Eklenti/69244,bakanlik-isletme-belgeli-ilcelere-gore-tesisler---site-.pdf?0 